\title{
Micellar Catalysis for Sustainable Hydroformylation
}

\author{
Francesca Migliorini, ${ }^{[a]}$ Filippo Dei, ${ }^{[a]}$ Massimo Calamante, ${ }^{[b]}$ Samuele Maramai, ${ }^{[a]}$ and \\ Elena Petricci*[a]
}

\begin{abstract}
It is here reported a fully sustainable and generally applicable protocol for the regioselective hydroformylation of terminal alkenes, using cheap commercially available catalysts and ligands, in mild reaction conditions $\left(70^{\circ} \mathrm{C}, 9 \mathrm{bar}, 40 \mathrm{~min}\right)$. The process can take advantages from both micellar catalysis and microwave irradiation to obtain the linear aldehydes as the major or sole regioisomers in good to high yields. The substrate scope is largely explored as well as the application of hydroformylation in tandem with intramolecular hemiacetalization
\end{abstract}

\section{Introduction}

Hydroformylation reaction is one of the most useful methods for the preparation of aldehydes by addition of hydrogen $\left(\mathrm{H}_{2}\right)$ and carbon monoxide $(\mathrm{CO})$ to double bonds. ${ }^{[1-3]}$ Aldehydes are very versatile and reactive functional groups usually used as intermediates for further transformations into alcohols, amines or condensation products, by also using domino and tandem protocols. ${ }^{[2]}$ The oxo process, as called by Otto Roelen, ${ }^{[1 a-b]}$ is the most applied catalytic atom-economic transformation in bulk and fine chemical industries for the synthesis of fine chemicals including Active Pharmaceutical Ingredients ${ }^{[4-5]}$ (i.e. Ilepatril, Omapatrilat, ${ }^{[6]}$ Zincophorin Methyl Ester, ${ }^{[7]}$ Naproxen $\left.{ }^{[8]}\right)$, fragrances (i.e. linalool, $\beta$-citronellene), ${ }^{[9]}$ detergents and natural products (i.e. Lepadiformine, ${ }^{[10]}(S)$-anabasine, (S)-nicotine, $(+)$-lupinine $\left.{ }^{[11]}\right)$. This homogeneous catalytic process can be mediated by different transition metals such as $\mathrm{Co}^{\left[1{ }^{[a, 12]}\right.} \mathrm{Ru}^{\left[{ }^{[13]}\right.}$ $\mathrm{Pt}^{[14]} \mathrm{Fe}^{[15]}$ and $\mathrm{Rh}^{[16]}$ in the presence of a specific ligands tuning the regio- and the chemoselectivities. ${ }^{[2,17]}$ Double bond hydrogenation and isomerization usually are the main side reactions in hydroformylation conditions. ${ }^{[18]}$ Classical hydroformylations require high pressures (10-100 bar) of $\mathrm{H}_{2}$ and $\mathrm{CO}$ mixtures (syngas) in different ratios (i.e. 1:1, 2:1, 4:1) in stainless steel

[a] F. Migliorini, F. Dei, Dr. S. Maramai, Prof. E. Petricci

Department of Biochemistry, Chemistry and Pharmacy

University of Siena

Via A. Moro

53100 Siena (Italy)

E-mail: petricci@unisi.it

[b] M. Calamante

CNR - ICCOM

Dipartimento di Chimica

Università degli Studi di Firenze

Via Madonna del Piano, 10

50019 Sesto Fiorentino, Firenze (Italy)

of 2021 The Authors. ChemCatChem published by Wiley-VCH GmbH. This is an open access article under the terms of the Creative Commons Attribution Non-Commercial NoDerivs License, which permits use and distribution in any medium, provided the original work is properly cited, the use is noncommercial and no modifications or adaptations are made. thus demonstrating the compatibility with a broad variety of functional groups. The reaction is efficient even in large scale and the catalyst and micellar water phase can be reused at least 5 times without any impact in reaction yields. The efficiency and sustainability of this protocol is strictly related to the in situ transformation of the aldehyde into the corresponding Bertagnini's salt that precipitates in the reaction mixture avoiding organic solvent mediated purification steps to obtain the final aldehydes as pure compounds.

autoclaves, for long reaction times (1-4 days), at high temperatures $\left(80-200^{\circ} \mathrm{C}\right)$, in not properly eco-friendly media such as toluene or THF. ${ }^{[1-3,19-20]}$

Since several years, our interest is focused on the development of processes for olefin hydroformylation in mild and more sustainable conditions, at low pressure of syngas, including taking advantages of microwave (MW) irradiation. ${ }^{[21-22]}$ These transformations have been successfully extended to heterogeneous catalytic systems, ${ }^{[23]}$ as well as to tandem and domino processes. ${ }^{[24]}$ However, the main limitation of the developed protocols is still represented by the use of toluene as the solvent, in pretty diluted conditions (i.e. $0.1 \mathrm{M}$ ), unsuitable for industrial applications. To overcome these limitations, we figured out that micellar catalysis could represent a valid option for our purposes. ${ }^{[25-26]}$ Water is a safe and non-toxic solvent used in a few transformations because of the low solubility of most organic compounds in it. ${ }^{[2]}$ This problem can be overcome by the use of surfactants generating supramolecular aggregates, such as micelles, able to solubilize organic lipophilic molecules in water. ${ }^{[25-26,28]}$ Moreover, micelles act as nanoreactors, containing all reactants and catalyst in very high concentrations, thus speeding up the reaction rates ${ }^{[25-26]}$ of many different metal-catalysed reactions, such as SuzukiMiyaura and Heck cross-coupling, ${ }^{[26]}$ hydrogen borrowing processes, ${ }^{[29]}$ and others. ${ }^{[28-30]}$

Hydroformylation in biphasic olefin/water system has been firstly reported 1975 in the patented OXEA process using the water soluble trisulfonated triphenylphoshine ligand (TPPTS). ${ }^{[3]]}$ Contemporary, Johnson Matthey patented the use of cationic surfactants in hydroformylation processes by using similar sulfonated phosphine ligands. ${ }^{[32]}$ Since the 80 's, many efforts have been dedicated to find optimal catalysts and conditions for aqueous (or aqueous/organic biphasic) hydroformylation, ${ }^{[32]}$ with only few of them leading to industrial applications. ${ }^{[34]}$ As indicated by Kamer and Laan: "There is still a need for an approach that meets all of the strict requirements of a technical two-phase process, such as complete catalyst retention, high activity and stability, high aldehyde selectivity, simple phase 
separation, and low ligand costs in order to be economically competitive with the currently used processes". ${ }^{[35]}$ The most recently reported and efficient protocols are mediated by surfactants in 3 phases microemulsions systems, involving not sustainable solvents (i.e. toluene, 1,4-dioxane), although finding very interesting industrial applications. ${ }^{[36-38]}$ The real micellar catalytic hydroformylation protocols reported still suffer from many limitations including low yields $(30-73 \%){ }^{[39]}$ the use of expensive ligands such as SulfoXantphos $(260 € / g$ versus the less expensive Xantphos $45 € / g)$, ${ }^{[39-40]}$ 6DPPon $(130 € / g),{ }^{[41]}$ tailor-made surfactants, ${ }^{[40,42]}$ or modified cyclodestrines ${ }^{[43]}$ usually associated with high syngas pressures (15-100 bar). In some cases, the process is just apparently green as extraction and column chromatography using high quantities of toxic solvents (i.e. $\mathrm{Et}_{2} \mathrm{O}$ ) are necessary, and no catalyst recover and recycle is investigated, thus negatively impacting in the $E$ Factor. ${ }^{[41]}$ The most challenging reports are represented by the tandem application of hydroformylation with biocatalysis for the synthesis of nonanitrile, ${ }^{[4]}$ still needing high syngas pressures and occurring with poor regioselectivity, and the use of supramolecular ion pairs for 1-octene hydroformylation in water. ${ }^{[45]}$ The substrate scope of all these reports is limited to 1octene, 1-dodecene or styrene without investigating any general application to functionalized olefins thus needing a further investigation for a completely green hydroformylation protocol of general applicability.

We here reported our contribution to a fully sustainable and generally applicable approach to the regioselective hydroformylation of terminal alkenes in water through the use of the commercially available surfactant $\mathrm{DL}$ - $\alpha$-Tocopherol methoxypolyethylene glycol succinate (TPGS-750-M), commercially available $\mathrm{Rh}(\mathrm{CO}) \mathrm{H}\left(\mathrm{PPh}_{3}\right)_{3}$ catalyst and the cheap ligand Xantphos under MW-irradiation at low pressures of syngas (9 bar). This green method allows to obtain linear aldehydes in mild conditions $\left(70^{\circ} \mathrm{C}\right.$ and 9 bar) and short reaction times (40-60 minutes), with high isolated yields and regioselectivities and no purification step or extraction with organic solvents. All of this independently from the substituents present on the starting olefins and with a full recovery of the catalyst and the micellar phase, that can be reused for at least 5 times without any impact in reaction yields.

\section{Results and Discussion}

Allylbenzene (1) was selected as the model substrate for optimizing the hydroformylation process. At first, reaction conditions similar to the one we already developed in toluene were tested: ${ }^{[7]}$ a suspension of 1 in TPGS-750-M (5 wt \%) in $\mathrm{H}_{2} \mathrm{O}$ was irradiated with $\mathrm{MW}$ in the presence of a $1: 1 \mathrm{CO} / \mathrm{H}_{2}$ mixture (9 bar), $\mathrm{Rh}(\mathrm{CO}) \mathrm{H}\left(\mathrm{PPh}_{3}\right)_{3}(2 \mathrm{~mol} \%)$, Xantphos $(\mathrm{Rh} / \mathrm{L} 1: 4)$ at $110^{\circ} \mathrm{C}$ for 10 min obtaining a $53 \%$ conversion into the corresponding aldehyde with a good regioselectivity (Figure 1). Starting from Pogrzeba and co-workers' observations, ${ }^{[39]} \mathrm{NaCl}$ (1 mol\%) was added to obtain better performances in term of catalyst stability and reaction yields. The expected product 2 were obtained in a

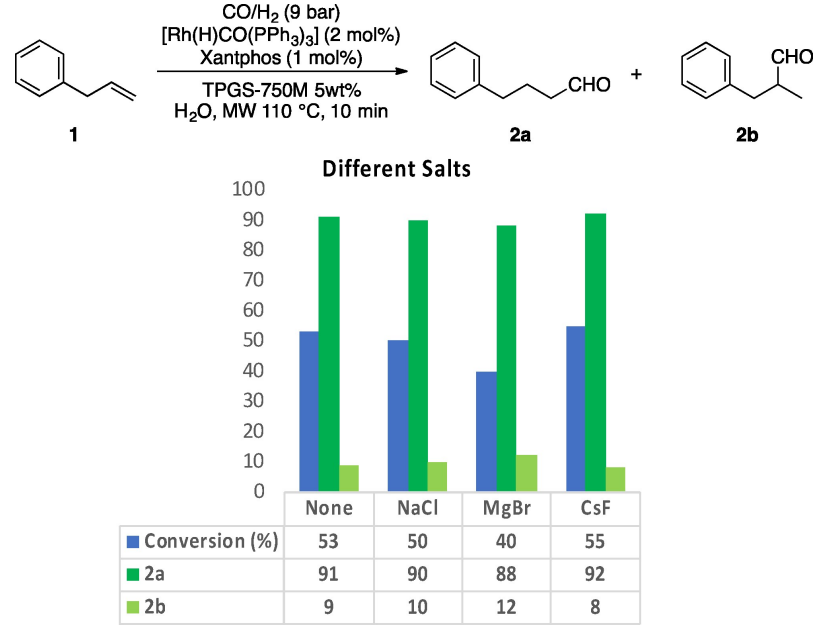

Figure 1. 1 (0.75 mmol), 1-dodecanal (internal standard, $0.075 \mathrm{mmol}), \mathrm{Rh}(\mathrm{CO})$ $\mathrm{H}\left(\mathrm{PPh}_{3}\right)_{3}(0.015 \mathrm{mmol})$, Xantphos $(0.06 \mathrm{mmol})$, salt $(0.0075 \mathrm{mmol})$, TPGS-750$\mathrm{M} 5$ wt \% in $\mathrm{H}_{2} \mathrm{O}(3 \mathrm{~mL}), \mathrm{MW} 110^{\circ} \mathrm{C}, 10 \mathrm{~min}$. Conversions are determined by $\mathrm{GC} / \mathrm{MS}$ (\%) as reported in SI.

$50 \%$ conversion with a good 9:1 regioselectivity towards liner aldehyde 2 a (Figure 1).

Even the use of different salts such as $\mathrm{MgBr}$ or $\mathrm{CsF}$ had a low impact on both conversions and regioselectivities probably caused by the use of a non-ionic surfactant in the reaction medium. ${ }^{[35]}$

Irradiation at higher temperatures in the presence of different ligands (Figure 2A) or for longer reaction times (Figure 2B) only enhance reduction or isomerization of the starting allylbenzene, together with the reduction of aldehyde $\mathbf{2}$ into the corresponding alcohol.

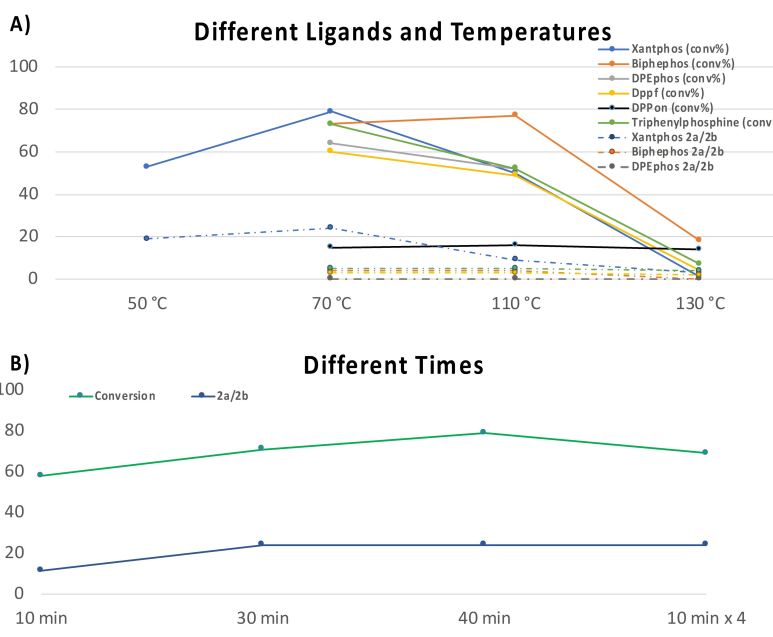

Figure 2. A) 1 (0.75 mmol), 1-dodecanal (internal standard, $0.075 \mathrm{mmol})$, $\mathrm{Rh}(\mathrm{CO}) \mathrm{H}\left(\mathrm{PPh}_{3}\right)_{3}(0.015 \mathrm{mmol}), \mathrm{L}(0.06 \mathrm{mmol}), \mathrm{TPGS}-750-\mathrm{M}(5 \mathrm{wt} \%)$ in $\mathrm{H}_{2} \mathrm{O}$ $(3 \mathrm{~mL}), \mathrm{MW}$ (max power $300 \mathrm{Watt}), 10 \mathrm{~min}$. Conversion determined by GC/ MS (\%) as report in ESI. B) 1 (0.75 mmol), 1-dodecanal (internal standard, $0.075 \mathrm{mmol}), \mathrm{Rh}(\mathrm{CO}) \mathrm{H}\left(\mathrm{PPh}_{3}\right)_{3}(0.015 \mathrm{mmol})$, Xantphos (0.06 mmol), TPGS-750 $\mathrm{M}(5 \mathrm{wt} \%)$ in $\mathrm{H}_{2} \mathrm{O}(3 \mathrm{~mL}), \mathrm{MW}$ (max power 300 Watt), $70^{\circ} \mathrm{C}$. Conversion determined by GC/MS (\%) as reported in SI. 
By using Biphephos as the ligand, an improvement in the conversion paralleled by a lower $4: 1$ regioselectivity was observed (Figure 2B). Surprisingly, the best results in terms of both conversion and selectivity were obtained lowering the temperature to $70^{\circ} \mathrm{C}$ and irradiating for 40 minutes (Figure $2 \mathrm{~B}$ and Table S1). Despite the different ligands tested (i.e. Biphephos, DPEphos, Dppf, 6-DPPon), the best performances in term of both conversions and regioselectivities towards the linear aldehyde $\mathbf{2 a}$ were obtained by using Xantphos. As expected, using $\mathrm{PPh}_{3}$ as the ligand or running the reaction in ligand free conditions, a drastic lower-down in regioselectivities was observed with similar conversions with respect to the ones observed with Xantphos (Table S1). It is interesting to note that the conversions are directly proportional to the $\log \mathrm{P}$ of the different ligands used, 6-DPPon $(\log \mathrm{P}=3.51)$ being the worst and Xantphos $(\log \mathrm{P}=10.39)$ the best one. Irradiating at $50^{\circ} \mathrm{C}$, shortening reaction times (30 minutes) or repeating 4 cycles of irradiation for $10 \mathrm{~min}$ each, negatively impacted the conversions (Figure $2 \mathrm{~A}$ and Table S1). It is worth noting that a temperature reduction is possible and necessary thanks to the particular combination of the MW effect on the triphasic micellar catalysis system: a gas-liquid-solid dispersion (see SI for reactions performed with traditional heating). We can probably associate the lower conversions observed at higher temperatures than $70^{\circ} \mathrm{C}$ to the minor interface area related to a lower down in droplet size responsible for a difficult mass transfer into the micelles. ${ }^{[39]}$ The best conditions observed for these transformations are: irradiation for 40 minutes at $70^{\circ} \mathrm{C}$ in presence of $\mathrm{Rh}(\mathrm{CO}) \mathrm{H}\left(\mathrm{PPh}_{3}\right)_{3}$, and Xantphos at 9 bar of syngas. The impact of $\mathrm{MW}$ irradiation on the reaction outcome was investigated by using a fixed power irradiation at 300 Watt (maximum temperature settled $70^{\circ} \mathrm{C}$ ), thus obtaining a full conversion (>99\%) and high regioselectivity ( $2 \mathrm{a} / 2 \mathrm{~b} 24: 1)$. The effect of lowering down the amount of catalyst from 2 to $1 \mathrm{~mol} \%$ (Entries 1-2, Table 1) was also evaluated. Lowering the amount of TPGS-750-M to $2.5 \mathrm{wt} \%$ had no impact on conversion (Entry 3, Table 1). No differences were observed at higher concentrations (Entry 4, Table 1), while the addition of sustainable co-solvents such as $2 \mathrm{Me}$-THF worsened the reaction rate (Table S1) as well as a change in the catalyst to ligand ratio (Entry 5, Table 1).

Different catalysts (Entries 6-7, Table 1) and ionic surfactants (Entries 8-9, Table 1) were tested, with no improvements observed. It is interesting to note that the structure of the surfactant directly impacts both on yield and regioselectivity, therefore demonstrating its active role in the reaction. This is further confirmed by the absence of any aldehyde while performing the transformation just in water without any surfactant (Entry 10, Table 1). Blank tests were also carried out to demonstrate the catalyst, the surfactant and the syngas roles in this transformation (Entries 10-12, Table 1).

In order to evaluate the sustainability of the overall process, a pilot reaction involving allylbenzene was performed in larger scale $(10 \mathrm{mmol}$ of allylbenzene). By using the best reaction conditions reported so far (Entry 3, Table 1 and Figure S1) at $0.5 \mathrm{mmol} / \mathrm{mL}$ concentration, the linear aldehyde $2 \mathrm{a}$ was recovered after extraction with AcOEt and column chromatog-
Table 1. Optimization of reaction conditions with MW constant irradiation

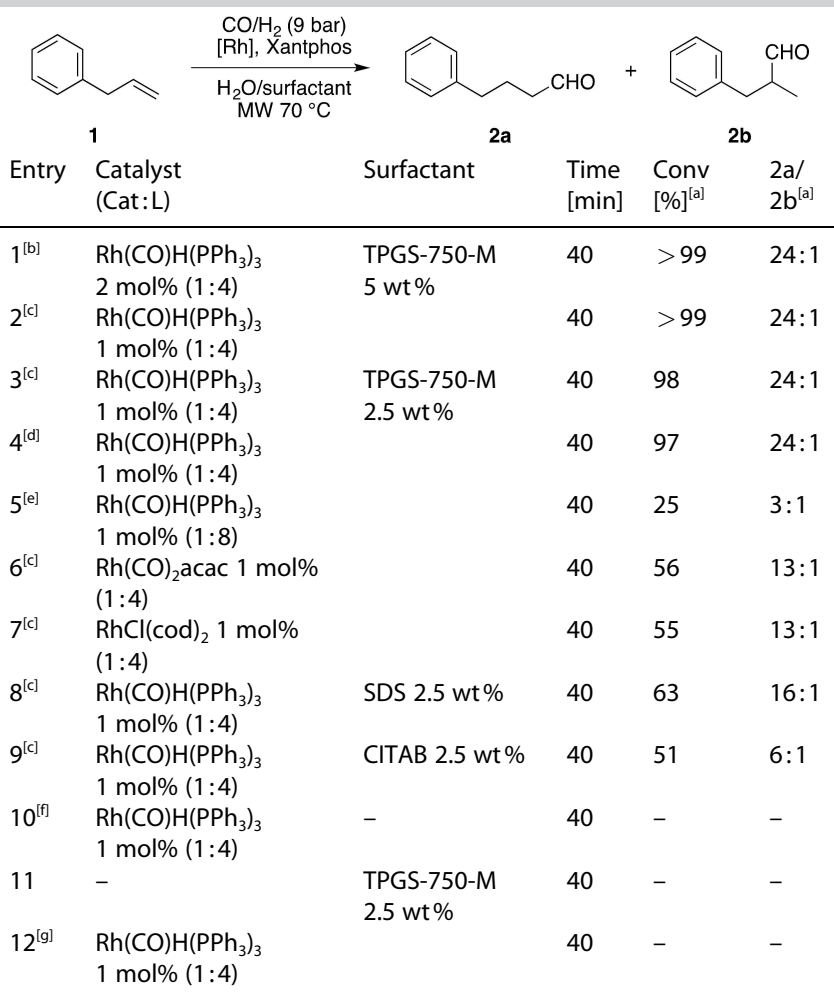

[a] Conversion determined by GC/MS. [b] $1(0.75 \mathrm{mmol})$, 1-dodecanal (internal standard, $0.075 \mathrm{mmol}), \mathrm{Rh}$ cat $(0.015 \mathrm{mmol})$, Xantphos ( $0.06 \mathrm{mmol})$, TPGS-750-M $5 \mathrm{wt} \%$ in $\mathrm{H}_{2} \mathrm{O}(3 \mathrm{~mL})$, MW dielectric heating at $70^{\circ} \mathrm{C}$ with fixed power irradiation at 300 Watt, cooling while heating ( $\max$ $\mathrm{T} 70^{\circ} \mathrm{C}$ ). [c] 1 ( $\left.0.75 \mathrm{mmol}\right), 1$-dodecanal (internal standard, $\left.0.075 \mathrm{mmol}\right), \mathrm{Rh}$ (CO) $\left(\mathrm{PPh}_{3}\right)_{3}(0.0075 \mathrm{mmol})$, Xantphos $(0.03 \mathrm{mmol})$, TPGS-750-M $2.5 \mathrm{wt} \%$ in $\mathrm{H}_{2} \mathrm{O}(3 \mathrm{~mL})$ if not differently reported, $\mathrm{MW}$ dielectric heating at $70^{\circ} \mathrm{C}$ with fixed power irradiation at 300 Watt, cooling while heating $\left(\max T 70^{\circ} \mathrm{C}\right)$. [d] $1(1.5 \mathrm{mmol}), 1$-dodecanal (internal standard, $0.15 \mathrm{mmol}), \mathrm{Rh}(\mathrm{CO}) \mathrm{H}\left(\mathrm{PPh}_{3}\right)_{3}$ $(0.015 \mathrm{mmol})$, Xantphos $(0.03 \mathrm{mmol})$, TPGS-750-M $2.5 \mathrm{wt} \%$ in $\mathrm{H}_{2} \mathrm{O}(3 \mathrm{~mL})$, MW dielectric heating at $70^{\circ} \mathrm{C}$ with fixed power irradiation at 300 Watt, cooling while heating $\left(\max \mathrm{T} 70^{\circ} \mathrm{C}\right)$. [e] $1(1.5 \mathrm{mmol}), 1$-dodecanal (internal standard, $0.15 \mathrm{mmol}), \mathrm{Rh}(\mathrm{CO}) \mathrm{H}\left(\mathrm{PPh}_{3}\right)_{3}(0.0075 \mathrm{mmol})$, Xantphos $(0.06 \mathrm{mmol})$, TPGS-750-M $2.5 \mathrm{wt} \%$ in $\mathrm{H}_{2} \mathrm{O}(3 \mathrm{~mL})$, MW dielectric heating at $70^{\circ} \mathrm{C}$ with fixed power irradiation at 300 Watt, cooling while heating (max T $70^{\circ} \mathrm{C}$ ). [f] same as [c] without TPGS-750-M. [g] Without syngas.

raphy, in $90 \%$ isolated yields ( 2 b was isolated in 3\% yield). With the aim of overcoming an organic work-up, thus avoiding the use of organic solvents in purification, the reaction was repeated by adding 1.5 eq. of $\mathrm{NaHSO}_{3}$ directly in the reaction mixture. In these conditions, $\mathbf{2}$ was directly obtained after microwave irradiation as the corresponding Bertagnini's salt that precipitates in micellar suspension (Figure S1).

The reaction mixture was filtered and the Bertagnini's salt treated with 1 equivalent of $\mathrm{NaOH} 10 \mathrm{M}$, with a full recovery of 2 as an oil in $>99 \%$ isolated yields by centrifugation and decantation. The possible catalyst recycle was evaluated by adding 1 and $\mathrm{NaHSO}_{3}$ to the micellar phase recovered after filtration and exposing the suspension to $\mathrm{MW}$ irradiation at $70^{\circ} \mathrm{C}$, for 40 minutes in the presence of syngas ( $9 \mathrm{bar}$ ). The conversion into 2 was complete (>99\%) and the process has been repeated for further 3 times without almost any impact in 
reaction yields, demonstrating a full recyclability of the catalyst (Figure 3 and S1).

The TON for a single reaction cycle is 99.1 while the TOF at $70 \%$ of conversion is $280 \mathrm{~h}^{-1}$ (for a confront of TOF values with other reported protocols see Table S2). The E-Factor for a single hydroformylation run on 1-octene is only 1.08 (Table S2); this value is comparable to the ones considered as suitable for the scale-up of industrial hydroformylation processes ${ }^{[39-40]}$ and better than the one reported in literature for 1-octene hydroformylation in the presence of surfactants (i.e. E-Factor 1035 in

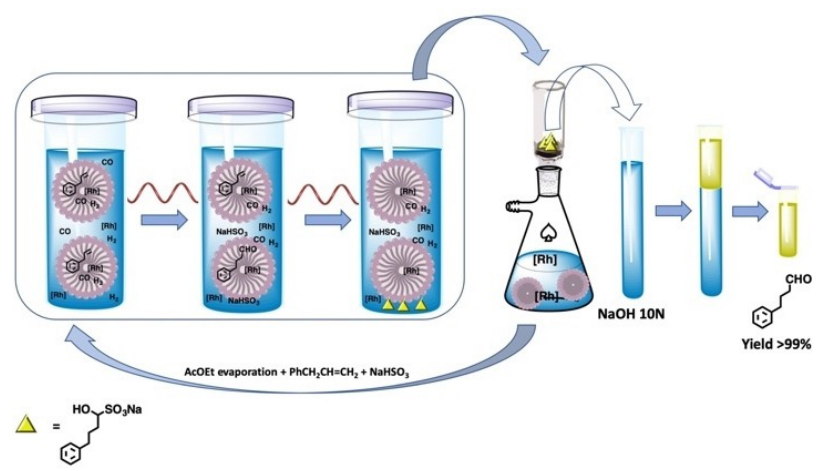

Figure 3. Catalyst and micelles recycle, work-up and purification
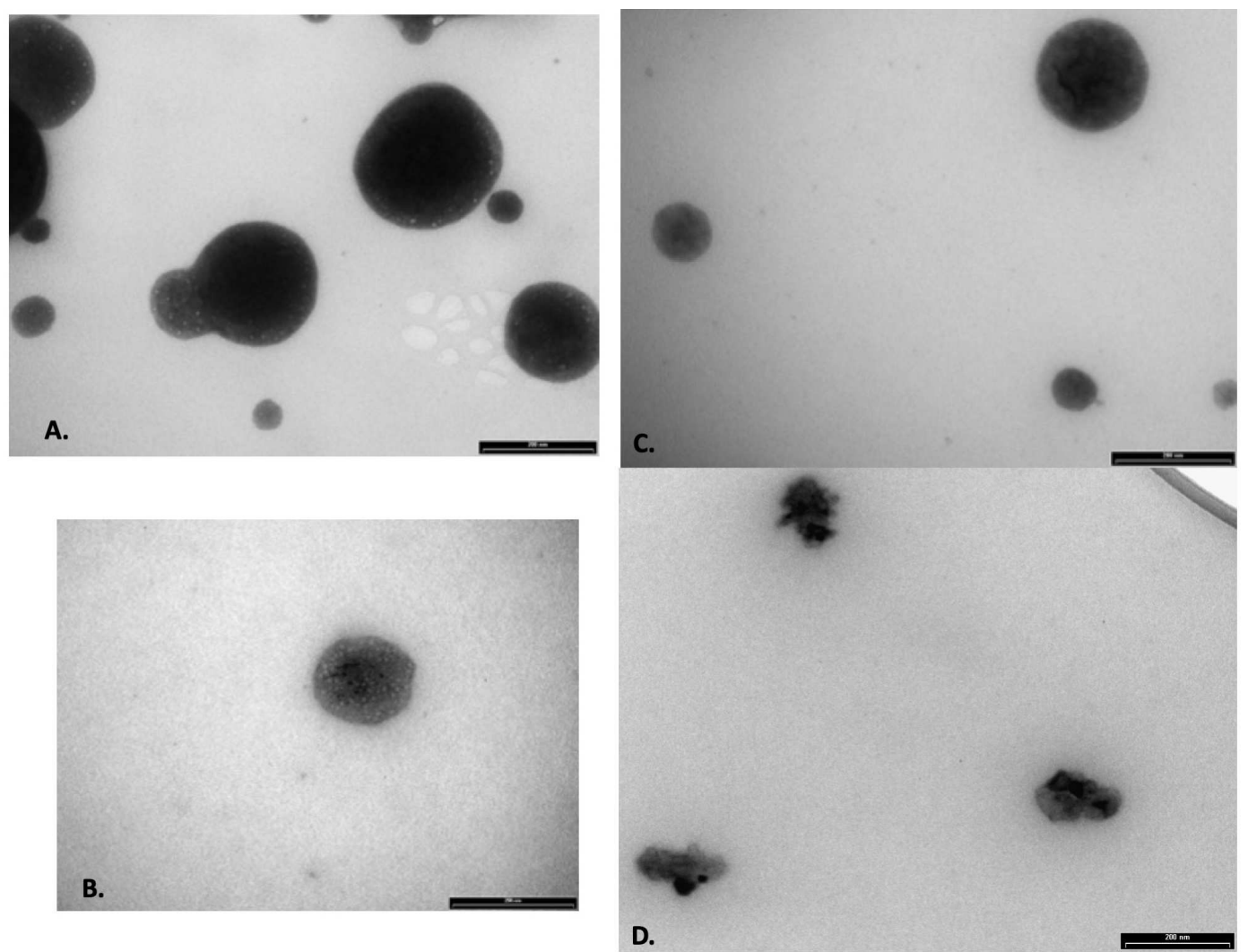

B.

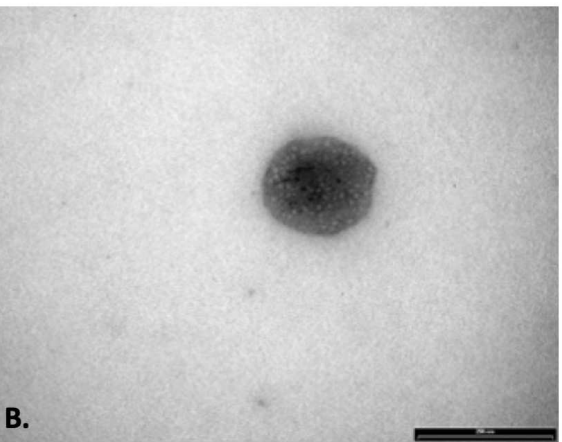

Figure 4. TEM analysis of: A) reaction mixture before irradiation: 1 (0.75 mmol), $\mathrm{Rh}(\mathrm{CO}) \mathrm{H}\left(\mathrm{PPh}_{3}\right)_{3}(0.015 \mathrm{mmol})$, Xantphos (0.06 mmol), TPGS-750-M (2.5 wt \%) in $\mathrm{H}_{2} \mathrm{O}(3 \mathrm{~mL})$; B) reaction mixture after $\mathrm{MW}$ dielectric heating at $70^{\circ} \mathrm{C}$ with fixed power irradiation at 300 Watt, cooling while heating (max T $70^{\circ} \mathrm{C}$ ) for 40 min; $\mathrm{C}$ ) reaction mixture after recycling micellar phase for 3 times; D) reaction mixture after MW dielectric heating at $120^{\circ} \mathrm{C}$ for 40 min. The TEM images are $200 \times 200 \mathrm{~nm}$ reference 41). We decide to further investigate micellar structure by DLS and TEM analysis to have a characterization of micelles after microwave irradiation and the catalyst recycling process, as a single example applying TPGS-750-M under microwave irradiation has been previously reported lacking for this data. ${ }^{[29 b]}$ As reported in Figure 3 and in S4, after microwave irradiation of the micellar suspension or the reaction mixture, we observe a higher homogeneity in micellar size together with a higher Z-potential value indicating an overall micellar stabilization. TEM analysis of the reaction mixture after irradiation at $70^{\circ} \mathrm{C}$ shows a multi-micelle structure in agreement with the data reported in the literature for traditional heating conditions. ${ }^{[25 \mathrm{~d}]}$ This structure is maintained after 4 cycles of catalyst recycle (Figure $4 \mathrm{~B}$ and $\mathrm{C}$ ).

$\mathrm{Rh}$ nanoparticles are not formed in the reaction conditions, while irradiating at higher temperatures (i.e. $120^{\circ} \mathrm{C}$ ) lower reaction yields contemporary with nanoparticles formation are observed together with micelles destabilization (Z-potential in Figure S3). These last findings demonstrate that $\mathrm{Rh}$ nanoparticle formation is detrimental for hydroformylation reactions and occurs irradiating at high temperature $\left(>100^{\circ} \mathrm{C}\right) .{ }^{31} \mathrm{P}-\mathrm{NMR}$ analysis of the reaction mixture after irradiation, after recycling, and after irradiation in previously reported hydroformylation conditions $^{[21]}$ indicated the presence of a stable catalytic species 
formed during MW heating different than the one obtained by using toluene as the reaction media (Figure S4-7).

Syngas solubility in micellar media has been found to be higher $(1.6 \mathrm{mmol} / \mathrm{L})$ than the observed in water at $1 \mathrm{~atm}$ $(1 \mathrm{mmol} / \mathrm{L})$, although this slight difference cannot be considered as responsible for the different reaction outcome in the different media.

With these findings in hands, we decided to explore the reaction versatility by using different terminal alkenes as substrates (Table 2 ).

We demonstrated that these MW assisted hydroformylation conditions are very tolerant to different functional groups (i.e. ester, amide, acetal, ether).

It is worth noting that the hydroformylation of industrially valuable long chain olefins, such as 1 -octene $\mathbf{3}$, occurs very efficiently producing linear nonanal in $95 \%$ isolated yields (Entry 1, Table 2). The process is chemoselective as it can be successfully performed even in the presence of reductionsensitive functional groups such as nitrile (Entry 2, Table 2), benzyl ether (Entry 9, Table 2), and internal alkenes (Entry 18, Table 2). Only terminal alkenes react even in the presence of internal ones (Entry 18, Table 2). Amides 9-14 react with variable yields and regioselectivities depending on the substituents on the aromatic ring. Particularly, electron withdrawing groups seem to negatively impact on reaction yields. The most difficult compounds to be hydroformylated are the solid ones (i.e. 7, 9, 11, 13, 19). In fact, most of the micellar catalysed processes reported in the literature have liquid starting materials or solid water soluble substrates. ${ }^{[25-27]}$

We figure out after many attempts (Table S3) that is possible to obtain linear aldehydes in good yields even starting from solid alkenes by using $2 \mathrm{~mol} \%$ of the catalyst instead of 1 (Entries 5, 7, 9, 11 and 17, Table 2). The reaction is compatible with the presence of silyloxy derivatives (Entries 13-12, Table 2), the performances being dependent on the hydrophobicity of the starting material. As expected, styrene 18 furnish the branched aldehyde 36 as the main reaction product in good yields (Entry 16, Table 2). Starting form quinoline 19, containing an hydroxy group, the 9-member cyclic hemiacetal is directly isolated in $53 \%$ yields with a full regioselectivity (Entry 17 , Table 2). Similar results were obtained starting from linalool 20: the cyclic hemiacetal is directly formed in $78 \%$ isolated yields from the linear aldehyde as the only reaction product (Entry 18, Table 2).

Starting form this interesting finding, we decided to investigate the possibility to obtain cyclic hemiacetals by hydroformylating alkenes containing alcohol moieties in $\beta$ position (Scheme 1).

Hemiacetals are obtained in good to acceptable yields. Again, the presence of electron donating moieties in the aromatic ring is usually associated with higher reaction yields.

\section{Conclusion}

We here demonstrate that is possible to perform hydroformylation reaction in water media taking advantages from both

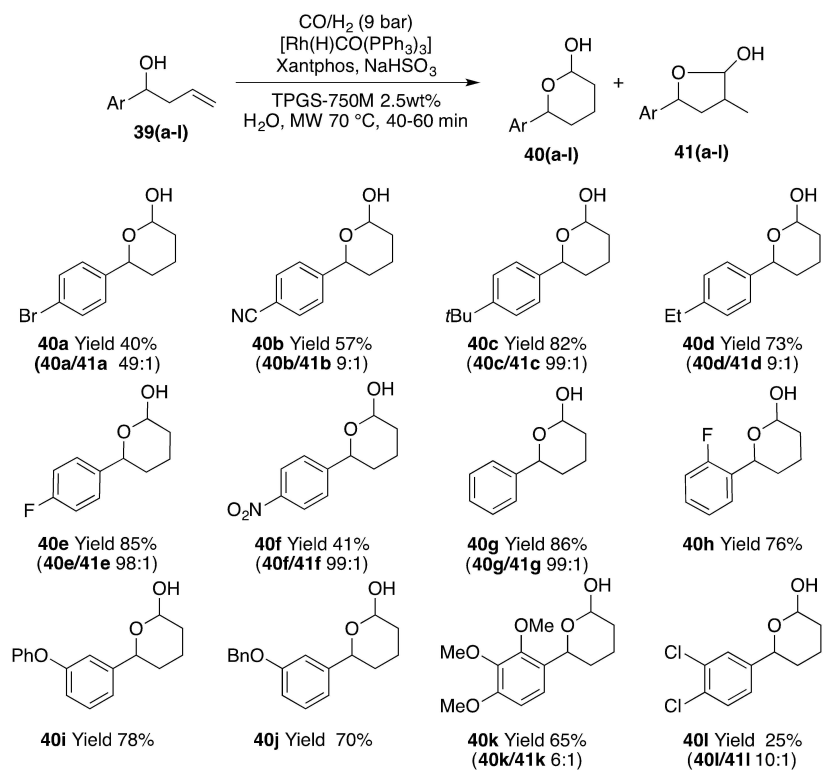

Scheme 1. Tandem hydroformylation and hemiacetalization

micellar catalysis and microwave irradiation. The process is fully eco-sustainable tanks to the use of $\mathrm{NaHSO}_{3}$ as additive that consents a full recovery of the final aldehydes and the active catalytic water-micellar phase without the use of any organic solvent (to see the impact on $\mathrm{NaHSO}_{3}$ on hydroformylation process see TLCs on Figure $2 \mathrm{~S}$ ). The process occurs with high regioselectivity towards linear aldehydes at low pressure of syngas (9 bar) and low temperature $\left(70^{\circ} \mathrm{C}\right)$ for an hydroformylation process, in only 40 minutes. The reaction can be done in $10 \mathrm{mmol}$ scale without affecting yields and selectivity and the micelles-catalyst system can be efficiently reused at least 5 times. The optimized protocol is compatible with different functional groups (i.e. amides, nitrile, nitro, ester, etc.) and can be used in tandem with intramolecular hemiacetalization for the synthesis of 5 or 6 member cyclic hemiacetals starting from hydroxy group containing starting alkenes. This work demonstrates how effective can be the coupling of micellar catalysis with microwave irradiation for the development of very efficient and sustainable hydroformylation protocols of general applicability. Micelles appear to be stable and more homogenous in term $f$ size distribution after irradiation. The process can be easily applied in lab scale by using commercial microwaves and we hope that it should find future applications in industrial scale as the hydroformylation in microemulsion has been recently investigated in miniplants ${ }^{[37]}$ and as microwave technology already found some applications in chemical production. ${ }^{[7-52]}$

\section{Experimental Section}

All reagents were used as purchased from commercial suppliers (i.e. Merk for surfactant and ligand, TCl for Rh catalyst) without further purification. Flash column chromatography was performed in glass columns using Merk silica gel $60 \AA$, 230-400 mesh particle 


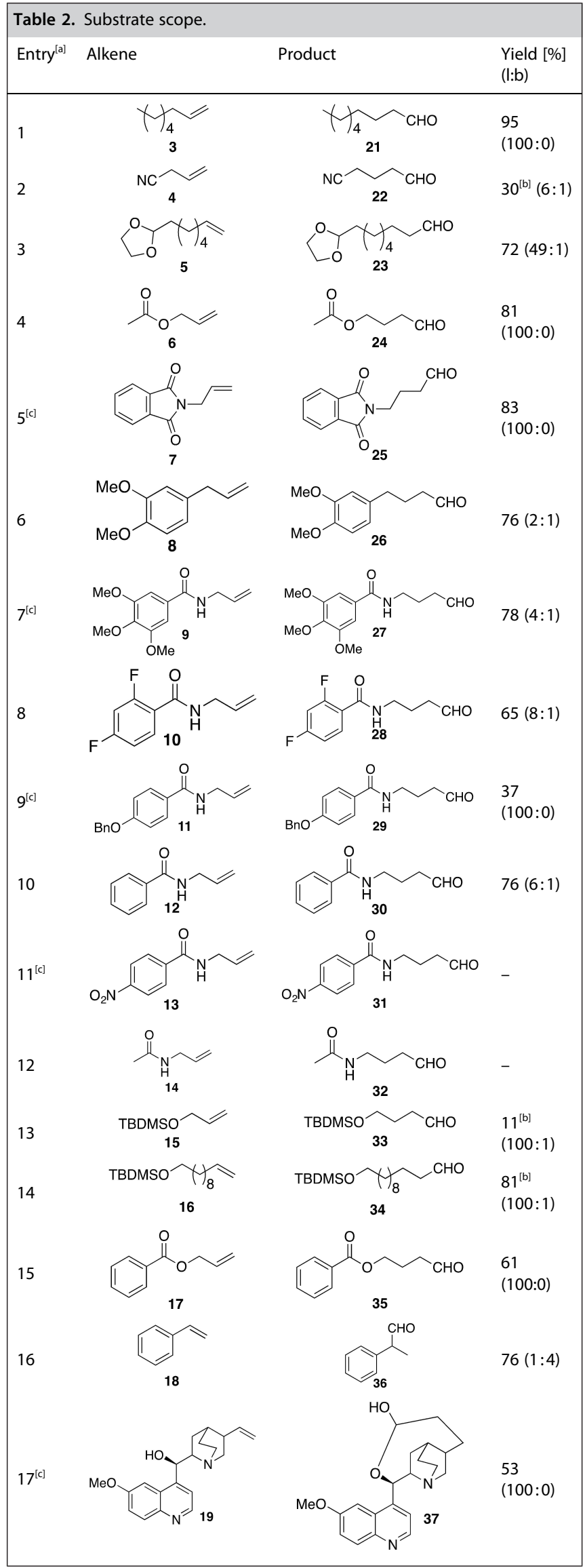

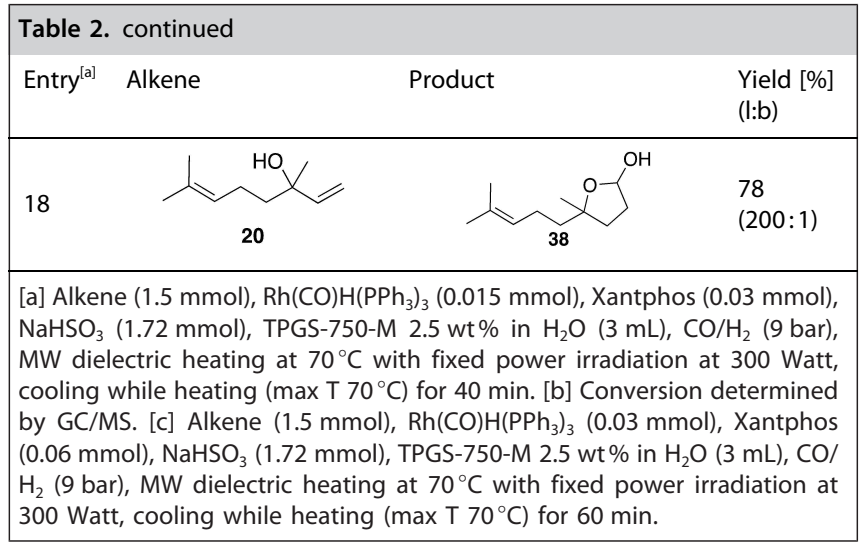

size Merck aluminum backed plates pre-coated with silica gel 60 (UV254) were used for analytical thin-layer chromatography and were visualized by staining with a solution $p$-anisaldehyde in $\mathrm{EtOH}$ or a $\mathrm{KMnO}_{4}$ solution. ${ }^{1} \mathrm{H} \mathrm{NMR},{ }^{13} \mathrm{C}$ and ${ }^{31} \mathrm{P}$ NMR spectra were recorded on $400 \mathrm{MHz}, 600 \mathrm{MHz}$, and $243 \mathrm{MHz}$ Bruker Advance NMR spectrometers. Deuterated chloroform and methanol were used as the solvents and chemical shift values $(\delta)$ are reported in parts per million (ppm) referring to the residual signals of the deuterated solvent ( $\delta 7.26$ for ${ }^{1} \mathrm{H}$ and $\delta 77.6$ for ${ }^{13} \mathrm{C}$ in $\mathrm{CDCl}_{3}, \delta 3.34$ for ${ }^{1} \mathrm{H}$ and $\delta$ 49.00 for ${ }^{13} \mathrm{C}$ in $\left.\mathrm{CD}_{3} \mathrm{OD}\right)$. For ${ }^{31} \mathrm{P}$ NMR spectra $(\delta)$ are reported in parts per million $(\mathrm{ppm})$ referring to triethylphosphate $(\delta=-0.82)$ in $\mathrm{CDCl}_{3} .{ }^{31} \mathrm{P}$ NMR spectra were acquired with ${ }^{1} \mathrm{H}$ decoupling. Data are represented as follows: chemical shift, multiplicity ( $s=$ singlet, $d=$ doublet, $d d=$ doublet of doublets, $d t=$ doublet of triplets, $t=$ triplet, $\mathrm{q}=$ quartet, $\mathrm{m}=$ multiplet or multiple resonances, $\mathrm{bs}=$ broad singlet), coupling constant $(J)$ in Hertz and the integration in ppm. Mass spectrometry data were collected on Varian Saturn $2000 \mathrm{GC} /$ MS spectrometer with ion trap detector and equipped with $30 \mathrm{~m}$ OV-101 capillary column, splitting injector at $240^{\circ} \mathrm{C}$.

Methods for $\mathrm{GC}$ analysis: A) $40^{\circ} \mathrm{C}-3 \mathrm{~min}, 40-200^{\circ} \mathrm{C} 10^{\circ} \mathrm{C} / \mathrm{min}-$ $17 \mathrm{~min}, 200-240^{\circ} \mathrm{C} 20^{\circ} \mathrm{C} / \mathrm{min}-5 \mathrm{~min}$; B) $40^{\circ} \mathrm{C}-3 \mathrm{~min}, 40-200^{\circ} \mathrm{C}$ $10^{\circ} \mathrm{C} / \mathrm{min}-16 \mathrm{~min}, 200-240^{\circ} \mathrm{C} 20^{\circ} \mathrm{C} / \mathrm{min}-8 \mathrm{~min}, 240-280^{\circ} \mathrm{C}$ $20^{\circ} \mathrm{C} / \mathrm{min}, 8 \mathrm{~min}$. Reactions carried out under MW dielectric heating were performed with a modified Discover microwave oven equipped with the $80 \mathrm{~mL}$ vial for reaction under pressure. ${ }^{[21]}$

Scanning transmission electron microscopy (STEM) and Energydispersive X-ray spectroscopy (EDS) analysis was done using a FIB/ SEM TESCAN GAIA 3 installed at the Microscopy Center (Ce.me.) at ICCOM-CNR (Florence). DLS, Z-potential measurements were done using a Zetasizer NanoZS90 instrument (Malvern, Worcestershire, UK).

\section{General method for ${ }^{31} \mathrm{P}$ NMR samples preparation}

A sample $(0.500 \mathrm{~mL})$ of the reaction mixture carried out on allylbenzene in toluene ${ }^{[21]}$ was evaporated under reduced pressure, dissolved in $0.400 \mathrm{~mL}$ of $\mathrm{CDCl}_{3}$ and analyzed by ${ }^{31} \mathrm{P}$ NMR (ns= 2048). A sample $(0.500 \mathrm{~mL})$ of the reaction mixture carried out on allylbenzene as reported in Method $A$ was extracted with AcOEt $(0.500 \mathrm{~mL})$, evaporated under reduced pressure dissolved in $0.400 \mathrm{~mL}$ of $\mathrm{CDCl}_{3}$ and analyzed by ${ }^{31} \mathrm{P}$ NMR (ns=2048). The micellar solution left was recovered and reused 3 times, and finally a sample $(0.500 \mathrm{~mL})$ of the reaction mixture was extracted with AcOEt $(0.500 \mathrm{~mL})$, evaporated under reduced pressure dissolved in $0.400 \mathrm{~mL}$ of $\mathrm{CDCl}_{3}$ and analyzed by ${ }^{31} \mathrm{P}$ NMR $(\mathrm{ns}=2048)$. Data are reported in Figures S5-8. 
Preparation of not commercially available starting alkenes 2(Dec-9-en-1-yl)-1,3-dioxolane (5). 10-undecenal $(2.38 \mathrm{~mL}$, $12.0 \mathrm{mmol})$ was dissolved in anhydrous ethylene glycol $(136 \mathrm{~mL}$, $2436.0 \mathrm{mmol})$ and a catalytic amount of $p$ TSA (193 mg, $1.02 \mathrm{mmol})$ in $40 \mathrm{~mL}$ of anhydrous toluene was added. The resulting mixture was heated at reflux for $1 \mathrm{~h}$. The mixture was extracted with $\mathrm{CH}_{2} \mathrm{Cl}_{2}$ $(3 \times 50 \mathrm{~mL})$, and the organic layer was evaporated after drying with anhydrous $\mathrm{Na}_{2} \mathrm{SO}_{4}$ furnishing the protected aldehyde. Yield: $81 \%$. GC-MS (m/z): 212; $R_{t}=16.563$ (Method A). ${ }^{1} \mathrm{H}$ NMR $\left(600 \mathrm{MHz}, \mathrm{CDCl}_{3}\right)$ d $5.83-5.68(\mathrm{~m}, 1 \mathrm{H}), 4.95(\mathrm{~d}, J=17.1 \mathrm{~Hz}, 1 \mathrm{H}), 4.89(\mathrm{~d}, J=10.0 \mathrm{~Hz}$, $1 \mathrm{H}), 4.80(\mathrm{t}, J=4.5 \mathrm{~Hz}, 1 \mathrm{H}), 3.98-3.87(\mathrm{~m}, 2 \mathrm{H}), 3.85-3.77(\mathrm{~m}, 2 \mathrm{H})$, $2.00(\mathrm{q}, J=6.5 \mathrm{~Hz}, 2 \mathrm{H}), 1.66-1.59(\mathrm{~m}, 2 \mathrm{H}), 1.41-1.22(\mathrm{~m}, 12 \mathrm{H}) .{ }^{13} \mathrm{C}$ NMR $\left(151 \mathrm{MHz}, \mathrm{CDCl}_{3}\right) \delta 139.1,114.1,104.7,64.8,33.9,33.7,29.5$, $29.5,29.3,29.1,28.9,24.0$. The spectral data were identical to those reported in the literature. ${ }^{[53]}$

2-Allylisoindoline-1,3-dione (7). To a solution of phthalimide (1.5 g, $10.2 \mathrm{mmol})$ in DMF $(10 \mathrm{~mL})$ were added $\mathrm{K}_{2} \mathrm{CO}_{3}(1.41 \mathrm{~g}, 10.2 \mathrm{mmol})$ and allyl bromide $(882 \mu \mathrm{L}, 10.2 \mathrm{mmol})$. After the solution was stirred for $16 \mathrm{~h}$ at room temperature, $\mathrm{EtO}_{2}(30 \mathrm{~mL})$ was added to the reaction mixture, and this latter was then washed with $\mathrm{NaCl}_{\mathrm{ss}}(3 \times$ $15 \mathrm{~mL}$ ). The organic layer was evaporated under reduced pressure after drying with anhydrous $\mathrm{Na}_{2} \mathrm{SO}_{4}$ to afford the desired compound. Yield: $87 \%$. GC-MS (m/z): 187; $R_{\mathrm{t}}=16.697$ (Method A). ${ }^{1} \mathrm{H}$ NMR $\left(600 \mathrm{MHz}, \mathrm{CDCl}_{3}\right) \delta 7.86(\mathrm{dd}, J=5.3,3.1 \mathrm{~Hz}, 2 \mathrm{H}), 7.72(\mathrm{dd}, J=$ $5.3,3.1 \mathrm{~Hz}, 2 \mathrm{H}), 5.95-5.81(\mathrm{~m}, 1 \mathrm{H}), 5.25(\mathrm{dd}, J=17.0,0.9 \mathrm{~Hz}, 1 \mathrm{H})$, $5.20(\mathrm{~d}, J=10.2 \mathrm{~Hz}, 1 \mathrm{H}), 4.30(\mathrm{~d}, J=5.7 \mathrm{~Hz}, 2 \mathrm{H}) .{ }^{13} \mathrm{C}$ NMR $(151 \mathrm{MHz}$, $\left.\mathrm{CDCl}_{3}\right) \delta 167.9,134.0,132.1,131.5,123.3,117.8,40.1$. The spectral data were identical to those reported in the literature. ${ }^{[54]}$

\section{General method for the formation of benzoyl allylamides 9- 10 and 12-13.}

A mixture the appropriate carboxylic acid $(16 \mathrm{mmol})$ in freshly distilled $\mathrm{SOCl}_{2}(12 \mathrm{~mL})$ was heated to reflux for $2 \mathrm{~h}$, then cooled to room temperature and evaporated under vacuum to dryness to afford quantitatively corresponding acid chlorides. In a dried flask under $\mathrm{N}_{2}$ atmosphere, a solution of allylamine $(1.8 \mathrm{~mL}, 24 \mathrm{mmol})$ and $\mathrm{Et}_{3} \mathrm{~N}(3.3 \mathrm{~mL}, 24 \mathrm{mmol})$ in dry $\mathrm{CH}_{2} \mathrm{Cl}_{2}(25 \mathrm{~mL})$ was cooled in an ice bath to $0^{\circ} \mathrm{C}$. Then, the appropriate benzoyl chloride $(16 \mathrm{mmol})$ was added dropwise. The solution was allowed to warm to room temperature and then stirred for $16 \mathrm{~h} . \mathrm{H}_{2} \mathrm{O}(15 \mathrm{~mL})$ was added and the organic layer was separated. The aqueous layer was extracted with $\mathrm{CH}_{2} \mathrm{Cl}_{2}(2 \times 30 \mathrm{~mL})$. The combined organic phases were washed with $\mathrm{NaCl}_{\mathrm{ss}}(15 \mathrm{~mL})$, dried over $\mathrm{Na}_{2} \mathrm{SO}_{4}$ and the solvent removed. The crude product was purified by precipitation or column chromatography on silica gel.

$\mathrm{N}$-Allyl-3,4,5-trimethoxybenzamide (9). The crude was solubilized in the minimum amount of $\mathrm{CH}_{2} \mathrm{Cl}_{2}(10 \mathrm{~mL})$ and petroleum ether $(50 \mathrm{~mL})$ was added slowly in order to obtain a white precipitate that was filtered on Büchner washing with cold petroleum ether. Yield: $70 \%$. ${ }^{1} \mathrm{H}$ NMR $\left(600 \mathrm{MHz}, \mathrm{CDCl}_{3}\right)$ : $\delta 7.02(\mathrm{~s}, 2 \mathrm{H}), 6.42(\mathrm{bs}, 1 \mathrm{H})$, 5.96-5.55 (m, 1H), $5.20(\mathrm{dd}, J=45.4,13.7 \mathrm{~Hz}, 2 \mathrm{H}), 4.04(\mathrm{~d}, J=5.7 \mathrm{~Hz}$, $2 \mathrm{H}), 3.87(\mathrm{~s}, 9 \mathrm{H}) .{ }^{13} \mathrm{C}$ NMR $\left(151 \mathrm{MHz}, \mathrm{CDCl}_{3}\right): \delta 167.1,153.2,140.9$, 134.2, 129.9, 116.7, 104.4, 60.9, 56.4, 42.7. Elemental Analysis Calcd for $\mathrm{C}_{13} \mathrm{H}_{17} \mathrm{NO}_{4}: \mathrm{C}, 62.14 ; \mathrm{H}, 6.82 ; \mathrm{N}, 5.57 ; \mathrm{O}, 25.47$. Found: $\mathrm{C}, 62.14 ; \mathrm{H}$, $6.82 ; \mathrm{N}, 5.57 ; \mathrm{O}, 25.47$

$\mathrm{N}$-Allyl-2,4-difluorobenzamide (10). The product was purified by means of flash chromatography using EtOAc in petroleum ether mixture as the eluent. Yield: $72 \%$. ${ }^{1} \mathrm{H}$ NMR $\left(600 \mathrm{MHz}, \mathrm{CDCl}_{3}\right): \delta$ 8.23-7.99 $(\mathrm{m}, 1 \mathrm{H}), 6.98-6.95(\mathrm{~m}, 1 \mathrm{H}), 6.86-6.82(\mathrm{~m}, 1 \mathrm{H}), 6.76$ (bs, $1 \mathrm{H}), 5.91$ (ddq, $J=15.2,10.0,5.0,4.5 \mathrm{~Hz}, 1 \mathrm{H}$ ), 5.21 (dd, $J=47.2$, $13.6 \mathrm{~Hz}, 2 \mathrm{H}), 4.08(\mathrm{~d}, J=5.7 \mathrm{~Hz}, 2 \mathrm{H}) .{ }^{13} \mathrm{C}$ NMR $\left(151 \mathrm{MHz}, \mathrm{CDCl}_{3}\right): \delta$ $165.6,162.3,160.1,133.9,117.6,116.5,112.3,104.4,104.0,42.4$.
$\mathrm{N}$-Allylbenzamide (12). The crude was purified by means of flash chromatography on silica gel using a petroleum ether $/ \mathrm{CH}_{2} \mathrm{Cl}_{2}$ mixture as the eluent. Yield: $78 \%$. ${ }^{1} \mathrm{H}$ NMR $\left(400 \mathrm{MHz}, \mathrm{CDCl}_{3}\right) \delta 7.75$ (d, $J=7.6 \mathrm{~Hz}, 2 \mathrm{H}), 7.50-7.35(\mathrm{~m}, 3 \mathrm{H}), 6.21$ (bs, 1H), 5.91 (qd, $J=10.8$ $5.7 \mathrm{~Hz}, 1 \mathrm{H}), 5.23(\mathrm{dd}, J=17.3,1.4 \mathrm{~Hz}, 1 \mathrm{H}), 5.15(\mathrm{dd}, J=10.2,1.2 \mathrm{~Hz}$, $1 \mathrm{H}), 4.11-4.02(\mathrm{~m}, 2 \mathrm{H}) .{ }^{13} \mathrm{C}$ NMR $\left(101 \mathrm{MHz}, \mathrm{CDCl}_{3}\right): \delta 167.5,134.6$, $134.3,131.6,128.7,127.1,116.7,42.5$. The spectral data were identical to those reported in the literature. ${ }^{[55]}$

$\mathrm{N}$-Allyl-4-nitrobenzamide (13). The product was purified by means of flash chromatography using EtOAc in petroleum ether mixture as the eluent. Yield: $78 \%$. ${ }^{1} \mathrm{H}$ NMR $\left(600 \mathrm{MHz}, \mathrm{CDCl}_{3}\right) \delta 8.28(\mathrm{~d}, J=$ $8.4 \mathrm{~Hz}, 2 \mathrm{H}), 7.96(\mathrm{~d}, J=8.4 \mathrm{~Hz}, 2 \mathrm{H}), 6.45(\mathrm{~s}, 1 \mathrm{H}), 6.01-5.88(\mathrm{~m}, 1 \mathrm{H})$, $5.28(\mathrm{~d}, J=17.1 \mathrm{~Hz}, 1 \mathrm{H}), 5.22(\mathrm{~d}, J=10.2 \mathrm{~Hz}, 1 \mathrm{H}), 4.11(\mathrm{t}, J=5.3 \mathrm{~Hz}$, 2H). ${ }^{13} \mathrm{C}$ NMR $\left(151 \mathrm{MHz}, \mathrm{CDCl}_{3}\right) \delta 165.4,149.6,140.0,133.4,128.2$ $123.9,117.4,42.8$. The spectral data were identical to those reported in the literature. ${ }^{[56]}$

$\mathrm{N}$-Allylacetamide (14). Allylamine $(2.63 \mathrm{~mL}, 35.0 \mathrm{mmol})$ was dissolved in dry $\mathrm{CH}_{2} \mathrm{Cl}_{2}(50 \mathrm{~mL})$ followed by the addition of $\mathrm{Et}_{3} \mathrm{~N}$ $(7.30 \mathrm{~mL}, 52.5 \mathrm{mmol})$ and dropwise addition of acetyl chloride $(2.75 \mathrm{~mL}, 38.5 \mathrm{mmol})$ at $0^{\circ} \mathrm{C}$. After stirring for 16 hours at room temperature $30 \mathrm{~mL}$ of $\mathrm{H}_{2} \mathrm{O}$ were added to the reaction. The organic phase was separated and the aqueous layer was extracted with $\mathrm{CH}_{2} \mathrm{Cl}_{2}(3 \times 50 \mathrm{~mL})$. The resulting organic layer was dried over anhydrous $\mathrm{Na}_{2} \mathrm{SO}_{4}$ and concentrated. The crude product was purified by silica gel flash chromatography using a mixture of EtOAc/petroleum ether $(5: 95)$ as the eluent. Yield: $55 \%$. GC-MS $(\mathrm{m} / \mathrm{z}): 99 ; \mathrm{R}_{\mathrm{t}}=7.812 \mathrm{~min}$ (Method A). ${ }^{1} \mathrm{H}$ NMR $\left(400 \mathrm{MHz}, \mathrm{CDCl}_{3}\right): \delta=$ $5.81(\mathrm{ddt}, J=17.0,10.2,5.8 \mathrm{~Hz}, 1 \mathrm{H}), 5.16(\mathrm{q}, J=17.0 \mathrm{~Hz}, 1 \mathrm{H}), 5.10(\mathrm{q}$, $J=10.1 \mathrm{~Hz}, 1 \mathrm{H}), 3.84(\mathrm{tt}, J=5.7,1.5 \mathrm{~Hz}, 2 \mathrm{H}), 1.99(\mathrm{~s}, 3 \mathrm{H}) .{ }^{13} \mathrm{C}$ NMR $\left(101 \mathrm{MHz}, \mathrm{CDCl}_{3}\right): \delta=170.1,134.3,116.3,42.2,23.6$. The spectral data were identical to those reported in the literature. ${ }^{[57]}$

(Allyloxy)(tert-butyl)dimethylsilane (15). Imidazole (1.16 g, $16.97 \mathrm{mmol})$ and TBDMSCl $(2.56 \mathrm{~g}, 16.97 \mathrm{mmol})$ were added to a solution of the alcohol $(11.31 \mathrm{mmol})$ in dry $\mathrm{CH}_{2} \mathrm{Cl}_{2}(35 \mathrm{~mL})$ at $0^{\circ} \mathrm{C}$. Stirring was continued at room temperature for $4 \mathrm{~h} . \mathrm{H}_{2} \mathrm{O}(20 \mathrm{~mL})$ was added and the organic layer was washed with $\mathrm{NaCl}_{\mathrm{ss}}(20 \mathrm{~mL})$ and concentrated after drying with anhydrous $\mathrm{Na}_{2} \mathrm{SO}_{4}$. The crude was purified by column chromatography on silica gel (20\% EtOAc in petroleum ether) to afford the title compound as a colorless liquid. Yield: $82 \%$. GC-MS (m/z): 172; Rt $=10.465 \mathrm{~min}$ (Method A). ${ }^{1} \mathrm{H}$ NMR $\left(400 \mathrm{MHz}, \mathrm{CDCl}_{3}\right) \delta 6.08-5.74(\mathrm{~m}, 1 \mathrm{H}), 5.25(\mathrm{~d}, J=17.0 \mathrm{~Hz}$, $1 \mathrm{H}), 5.05(\mathrm{~d}, \mathrm{~J}=9.0 \mathrm{~Hz}, 1 \mathrm{H}), 4.32-4.01(\mathrm{~m}, 2 \mathrm{H}), 0.92(\mathrm{~s}, 9 \mathrm{H}), 0.20(\mathrm{~s}$, $6 \mathrm{H}) ;{ }^{13} \mathrm{C}$ NMR $\left(101 \mathrm{MHz}, \mathrm{CDCl}_{3}\right) \delta 137.5,113.9,64.1,25.9,18.4,-5.3$. The spectral data were identical to those reported in the literature. ${ }^{[56]}$

tert-Butyldimethyl(undec-10-en-1-yloxy)silane (16). $\quad \mathrm{NaBH}_{4}$ ( $900 \mathrm{mg}, 23.8 \mathrm{mmol})$ was added to a solution of 10-undecenal $(2.38 \mathrm{~mL}, 11.9 \mathrm{mmol})$ in dry $\mathrm{MeOH}(50 \mathrm{~mL})$ at $0{ }^{\circ} \mathrm{C}$. After stirring for $1 \mathrm{~h}$ at $0^{\circ} \mathrm{C}, \mathrm{NH}_{4} \mathrm{Cl}_{\mathrm{ss}}(25 \mathrm{~mL})$ was added. The organic phase was separated and evaporated after drying with anhydrous $\mathrm{Na} 2 \mathrm{SO} 4$ Yield: $95 \%$. GC-MS (m/z): 170; Rt $=14.116 \mathrm{~min}$ (Method A). ${ }^{1} \mathrm{H}$ NMR $\left(400 \mathrm{MHz}, \mathrm{CDCl}_{3}\right): \delta$ 5.92-5.71 $(\mathrm{m}, 1 \mathrm{H}), 5.08-4.86(\mathrm{~m}, 2 \mathrm{H}), 3.73-3.55$ $(\mathrm{m}, 2 \mathrm{H}), 2.13-1.96(\mathrm{~m}, 2 \mathrm{H}), 1.65-.49(\mathrm{~m}, 2 \mathrm{H}), 1.47-1.18(\mathrm{~m}, 13 \mathrm{H}) .{ }^{13} \mathrm{C}$ NMR $\left(101 \mathrm{MHz}, \mathrm{CDCl}_{3}\right): \delta 139.3,114.2,63.2,33.9,32.9,29.7,29.5$, 29.0, 25.9. The spectral data were identical to those reported in the literature. ${ }^{[58]}$ From the previous intermediate alcohol, the title compound was obtained as a colorless liquid following the same procedure reported for 15 . Yield: $65 \%$. GC-MS (m/z): 284; $\mathrm{Rt}=$ $17.876 \mathrm{~min}$ (Method A). ${ }^{1} \mathrm{H}$ NMR $\left(600 \mathrm{MHz}, \mathrm{CDCl}_{3}\right): \delta 5.81$ (ddt, $J=$ $17.1,10.2,6.8 \mathrm{~Hz}, 1 \mathrm{H}), 5.03-4.98(\mathrm{~m}, 1 \mathrm{H}), 4.95-4.91(\mathrm{~m}, 1 \mathrm{H}), 3.59(\mathrm{t}$, $J=6.7 \mathrm{~Hz}, 2 \mathrm{H}), 2.10-2.02(\mathrm{~m}, 2 \mathrm{H}), 1.57-1.48(\mathrm{~m}, 2 \mathrm{H}), 1.41-1.36(\mathrm{~m}$, $2 \mathrm{H}), 1.33-1.23(\mathrm{~m}, 10 \mathrm{H}), 0.09(\mathrm{~s}, 9 \mathrm{H}), 0.05(\mathrm{~s}, 6 \mathrm{H}) .{ }^{13} \mathrm{C}$ NMR $\left(151 \mathrm{MHz}, \mathrm{CDCl}_{3}\right): \delta 139.2,114.2,63.3,33.8,32.8,29.5,29.4,29.2$, 
$28.9,26.0,25.8,18.4,-5.3$. The spectral data were identical to those reported in the literature. ${ }^{[59]}$

Allyl benzoate (17). In a dry round bottom flask charged with benzoic acid $(1.5 \mathrm{~g}, 12.30 \mathrm{mmol})$ and dry $\mathrm{CH}_{2} \mathrm{Cl}_{2}(40 \mathrm{~mL})$ allyl alcohol $(557 \mu \mathrm{L}, 8.2 \mathrm{mmol})$ and DMAP $(100 \mathrm{mg}, 0.82 \mathrm{mmol})$ were added. The solution was cooled to $0{ }^{\circ} \mathrm{C}$ and stirred for 15 minutes before the addition of DCC $(3.4 \mathrm{~g}, 16.4 \mathrm{mmol})$. The reaction was stirred at room temperature for $16 \mathrm{~h}$ under $\mathrm{N}_{2}$. The mixture was filtered, concentrated in vacuo, and the crude was purified by flash chromatography on silica gel (20\% EtOAc in petroleum ether) to afford a clear product as a colorless oil. Yield: $53 \%$. GC-MS (m/z): 163; $\mathrm{R}_{\mathrm{t}}=12.670 \mathrm{~min}$ (Method A). ${ }^{1} \mathrm{H}$ NMR $\left(400 \mathrm{MHz}, \mathrm{CDCl}_{3}\right): \delta 8.04$ (d, J=8.0 Hz, 2H), $7.52(\mathrm{t}, J=7.3 \mathrm{~Hz}, 1 \mathrm{H}), 7.41(\mathrm{t}, J=7.2 \mathrm{~Hz}, 2 \mathrm{H}), 6.02$ (ddt, $J=16.3,10.7,5.4 \mathrm{~Hz}, 1 \mathrm{H}), 5.32(\mathrm{dd}, J=50.5,14.1 \mathrm{~Hz}, 2 \mathrm{H}), 4.80$ $(d, J=5.4 \mathrm{~Hz}, 2 \mathrm{H}) .{ }^{13} \mathrm{C}$ NMR $\left(151 \mathrm{MHz}, \mathrm{CDCl}_{3}\right): \delta 166.3,133.1,132.2$ $130.1,129.7,128.5,118.3,65.6$. The spectral data were identical to those reported in the literature. ${ }^{[58]}$

Synthesis of $\mathrm{N}$-allyl-4-(benzyloxy)benzamide (11): Benzyl 4-(benzyloxy)benzoate: Dry $\mathrm{K}_{2} \mathrm{CO}_{3}(15 \mathrm{~g}, 110.0 \mathrm{mmol})$ was added to a solution of 4-hydroxybenzoic acid $(1.5 \mathrm{~g}, 11.0 \mathrm{mmol})$ in dry acetone $(81 \mathrm{~mL})$ at room temperature. After stirred for 30 minutes, benzyl bromide $(5.2 \mathrm{~mL}, 44.0 \mathrm{mmol})$ was added dropwise and the reaction was stirred for another 30 minutes at room temperature. The mixture was heated to reflux for $16 \mathrm{~h} . \mathrm{K}_{2} \mathrm{CO}_{3}$ was filtered on Büchner washing with acetone and the filtrate was evaporated under reduced pressure. The product was precipitated with petroleum ether $(30 \mathrm{~mL})$ and filtrated on Büchner washing the white powder with cold petroleum ether. Yield: $92 \%$. ${ }^{1} \mathrm{H}$ NMR $\left(600 \mathrm{MHz}, \mathrm{CDCl}_{3}\right) \delta 8.07(\mathrm{~d}, J=8.7 \mathrm{~Hz}, 2 \mathrm{H}), 7.51-7.32(\mathrm{~m}, 8 \mathrm{H}), 7.02$ $(\mathrm{d}, J=8.7 \mathrm{~Hz}, 2 \mathrm{H}), 5.37(\mathrm{~s}, 2 \mathrm{H}), 5.13(\mathrm{~s}, 2 \mathrm{H}) .{ }^{13} \mathrm{C}$ NMR $(151 \mathrm{MHz}$, $\left.\mathrm{CDCl}_{3}\right) \delta 166.2,131.8,128.7,128.6,128.3,128.2,128.1,127.5,114.5$, $70.1,66.5$. The spectral data were identical to those reported in the literature. ${ }^{[59]}$

4-(Benzyloxy)benzoic acid: $10 \mathrm{~N} \mathrm{NaOH}(6 \mathrm{~mL}, 59.43 \mathrm{mmol})$ was added to a suspension of intermediate benzyl 4-(benzyloxy) benzoate $(2.7 \mathrm{~g}, 8.49 \mathrm{mmol})$ in $\mathrm{MeOH}(85 \mathrm{~mL})$. The mixture was heated at reflux for $1 \mathrm{~h}$ then concentrated under reduced pressure. The residue was poured into $\mathrm{H}_{2} \mathrm{O}(50 \mathrm{~mL})$ and washed with petroleum ether $(25 \mathrm{~mL})$. The aqueous phase was acidified until $\mathrm{pH}=2$ with $\mathrm{HCl} 4 \mathrm{~N}$ until the formation of a white solid was observed. This latter was filtered on Büchner, washed with cold $\mathrm{H}_{2} \mathrm{O}$ and dried in vacuo. Yield: $80 \%$. ${ }^{1} \mathrm{H}$ NMR $\left(600 \mathrm{MHz}, \mathrm{CD}_{3} \mathrm{OD}\right) \delta 7.93$ $(\mathrm{d}, J=8.5 \mathrm{~Hz}, 2 \mathrm{H}), 7.45-7.27(\mathrm{~m}, 5 \mathrm{H}), 6.98(\mathrm{~d}, J=8.5 \mathrm{~Hz}, 2 \mathrm{H}), 5.12(\mathrm{~s}$, 2H). ${ }^{13} \mathrm{C}$ NMR $\left(151 \mathrm{MHz}, \mathrm{CD}_{3} \mathrm{OD}\right) \delta 161.6,131.2,128.2,127.7$ (2 C), $127.2,113.9,69.7$. The spectral data were identical to those reported in the literature. ${ }^{[60]}$

N-Allyl-4-(benzyloxy)benzamide (11): A mixture of allylamine (539 $\mu \mathrm{L}, 7.18 \mathrm{mmol})$, 4-(benzyloxy)benzoic acid $(1.8 \mathrm{~g}, 7.90 \mathrm{mmol})$, $\mathrm{EDCl}(1.4 \mathrm{~mL}, 7.90 \mathrm{mmol})$ and $\mathrm{HOBt}(1.07 \mathrm{~g}, 7.90 \mathrm{mmol})$ in anhydrous DMF $(20 \mathrm{~mL})$ was stirred at room temperature for $16 \mathrm{~h} . \mathrm{H}_{2} \mathrm{O}$ $(30 \mathrm{~mL})$ was added and the mixture was extracted with $\mathrm{Et}_{2} \mathrm{O}(3 \times$ $30 \mathrm{~mL}$ ). The organic layer was washed with $\mathrm{NaCl}_{\mathrm{ss}}(30 \mathrm{~mL})$, dried over dry $\mathrm{Na}_{2} \mathrm{SO}_{4}$, filtered and concentrated under reduced pressure. The resulting residue was purified by flash chromatography $(20 \%$ EtOAc in petroleum ether) to give the desired product. Yield: $54 \%$ ${ }^{1} \mathrm{H}$ NMR $\left(600 \mathrm{MHz}, \mathrm{CD}_{3} \mathrm{OD}\right): \delta 7.76(\mathrm{~d}, J=8.4 \mathrm{~Hz}, 2 \mathrm{H}), 7.43(\mathrm{~d}, J=$ $7.5 \mathrm{~Hz}, 2 \mathrm{H}), 7.39(\mathrm{t}, J=7.5 \mathrm{~Hz}, 1 \mathrm{H}), 7.35(\mathrm{~d}, J=7.2 \mathrm{~Hz}, 2 \mathrm{H}), 6.99(\mathrm{~d}$, $J=8.5 \mathrm{~Hz}, 2 \mathrm{H}), 6.29(\mathrm{bs}, 1 \mathrm{H}), 5.93(\mathrm{ddt}, J=16.2,10.7,5.6 \mathrm{~Hz}, 1 \mathrm{H})$, $5.21(\mathrm{dd}, J=48.5,13.6 \mathrm{~Hz}, 2 \mathrm{H}), 5.10(\mathrm{~s}, 2 \mathrm{H}), 4.06(\mathrm{~d}, J=5.8 \mathrm{~Hz}, 2 \mathrm{H})$. ${ }^{13} \mathrm{C}$ NMR $\left(151 \mathrm{MHz}, \mathrm{CD}_{3} \mathrm{OD}\right): \delta 166.9,161.4,136.4,134.2,129.0$, $128.8,128.7,128.2,127.5,127.0,125.3,120.3,116.5,114.7,109.4$ 70.1, 42.4 .

\section{General methods for the hydroformylation reaction}

Method A (for liquid alkenes). A $80 \mathrm{~mL}$ MW tube was charged with a solution of TPGS-750 M (2.5 wt \% in $\left.\mathrm{H}_{2} \mathrm{O}, 3 \mathrm{~mL}\right)$ and alkene (2.25 mmol, $0.75 \mathrm{M}$ solution). Then $\mathrm{NaHSO}_{3}(269 \mathrm{mg}, 2.59 \mathrm{mmol})$, $\mathrm{Rh}(\mathrm{CO}) \mathrm{H}\left(\mathrm{PPh}_{3}\right)_{3} \quad(21 \mathrm{mg}, \quad 0.0225 \mathrm{mmol})$ and Xantphos $(52 \mathrm{mg}$, $0.09 \mathrm{mmol}$ ) were added. The yellow suspension was stirred for 5 minutes under $\mathrm{N}_{2}$. The mixture was subjected to 3 cycles of vacuum/syngas inside the microwave cavity. Syngas was added since $130 \mathrm{psi}\left(8.8 \mathrm{bar}\right.$ ) are detected, and irradiated at $70^{\circ} \mathrm{C}$ for 40 minutes cooling while heating with a fixed power of 300 Watt. After irradiation the mixture was cooled-down to room temperature and the internal gas released by opening the external pressure valve. The mixture was filtered on Büchner washing with EtOAc $(5 \mathrm{~mL})$ to afford the bisulfite adduct as a crystalline powder that was solubilized in $\mathrm{H}_{2} \mathrm{O}$. If no precipitation was observed, the mixture was extracted with EtOAc $(9 \mathrm{~mL})$. Depending on the substrate, $\mathrm{NaOH} 10 \mathrm{~N}$ or $\mathrm{HCl} 4 \mathrm{~N}$ was added to the aqueous phase since $\mathrm{pH}=$ 8 or $\mathrm{pH}=2$, respectively. EtOAc $(9 \mathrm{~mL})$ was added and the mixture stirred at r.t. for 15 minutes. The two phases were separated and the organic phase was washed with $\mathrm{NaCl}_{\mathrm{ss}}(2 \times 5 \mathrm{~mL})$ and $\mathrm{H}_{2} \mathrm{O}$ $(5 \mathrm{~mL})$, dried with dry $\mathrm{Na}_{2} \mathrm{SO}_{4}$, filtered, evaporated under reduced pressure and analyzed by GC/MS or ${ }^{1} \mathrm{H}-\mathrm{NMR}$, furnishing the desired aldehyde (or the hemiacetal in a 1:1 diastereoisomeric mixture, see Scheme 1).

Method $B$ (for solid alkenes). A $80 \mathrm{~mL} \mathrm{MW}$ tube was charged with a solution of TPGS-750 M (2.5 wt \% in $\left.\mathrm{H}_{2} \mathrm{O}, 3 \mathrm{~mL}\right)$ and alkene (2.25 mmol, $0.75 \mathrm{M})$. Then $\mathrm{NaHSO}_{3}(269 \mathrm{mg}, 2.59 \mathrm{mmol}), \mathrm{Rh}(\mathrm{CO})$ $\mathrm{H}\left(\mathrm{PPh}_{3}\right)_{3}(42 \mathrm{mg}, 0.045 \mathrm{mmol})$ and Xantphos (104 mg, $0.18 \mathrm{mmol}$ ) were added. The suspension was vigorously stirred for 15 minutes under $\mathrm{N}_{2}$. The mixture was subjected to 3 cycles of vacuum/syngas inside the microwave cavity. Syngas was added since 130 psi (8.8 bar) are detected, and irradiated at $70^{\circ} \mathrm{C}$ for 60 minutes cooling while heating with a fixed power of 300 Watt. After irradiation the mixture was cooled-down to room temperature and the internal gas released by opening the external pressure valve. The mixture was worked up as for Method A.

When necessary, the crude was purified by chromatography on silica gel using EtOAc in petroleum ether as the eluent (see single methods for ratios). The yields are referred to the isolated linear products. If not described, the branched products were not isolated from the crude materials.

4-Phenylbutanal ( $2 \mathrm{a})$. The title compound was obtained following general method $A$, starting from allylbenzene and using $10 \mathrm{~N} \mathrm{NaOH}$ during the work-up. Yield: $86 \%$. GC/MS (m/z): 149; $R_{t}=12.744 \mathrm{~min}$ (Method A). ${ }^{1} \mathrm{H}$ NMR $\left(400 \mathrm{MHz}, \mathrm{CDCl}_{3}\right): \delta 9.73(\mathrm{~s}, 1 \mathrm{H}), 7.28(\mathrm{t}, J=$ $7.3 \mathrm{~Hz}, 2 \mathrm{H}), 7.18(\mathrm{q}, J=7.5 \mathrm{~Hz}, 3 \mathrm{H}), 2.65(\mathrm{t}, J=7.2 \mathrm{~Hz}, 2 \mathrm{H}), 2.43(\mathrm{t}, J=$ $7.4 \mathrm{~Hz}, 2 \mathrm{H}), 1.95(q, J=8 \mathrm{~Hz}, 2 \mathrm{H}) .{ }^{13} \mathrm{C}$ NMR $\left(101 \mathrm{MHz}, \mathrm{CDCl}_{3}\right): \delta 202.5$, $141.3,129.1,128.9,128.5,128.3,126.2,43.2,35.0,23.7$. The spectral data were identical to those reported in the literature. ${ }^{[6]]}$

Nonanal (21). The title compound was obtained following general method A starting from 1-octene and using $10 \mathrm{~N} \mathrm{NaOH}$ during the work-up. Yield: $90 \%$. GC/MS (m/z): 142; $\mathrm{R}_{\mathrm{t}}=10.818 \mathrm{~min}$ (Method A). ${ }^{1} \mathrm{H}$ NMR $\left(400 \mathrm{MHz}, \mathrm{CDCl}_{3}\right) \delta 9.73(\mathrm{t}, J=1.8 \mathrm{~Hz}, 1 \mathrm{H}), 2.38(\mathrm{td}, J=7.3$, $1.7 \mathrm{~Hz}, 2 \mathrm{H}), 1.61-1.57(\mathrm{~m}, 2 \mathrm{H}), 1.26-1.23(\mathrm{~m}, 10 \mathrm{H}), 0.84(\mathrm{t}, J=6.3 \mathrm{~Hz}$, 3H). ${ }^{13} \mathrm{C}$ NMR $\left(101 \mathrm{MHz}, \mathrm{CDCl}_{3}\right) \delta 203.1,44.0,31.9,29.4,29.3,29.2$, $22.8,22.2,14.2$. The spectral data were identical to those reported in the literature. ${ }^{[62]}$

5-Oxopentanenitrile (22a), 3-methyl-4-oxobutanenitrile(22 b) (22a/22 b 85:15). The compounds mixture was obtained following general method $A$, starting from allyl cyanide and using $10 \mathrm{~N} \mathrm{NaOH}$ during the work-up. Purification: by means of chromatography on silica gel, using an increasing gradient of EtAOc in petroleum ether, it was not possible to isolate the linear aldehyde to the branched 
one. Yield: $41 \%$ (of the mixture). GC/MS (m/z): 98; $R_{t}$ linear aldehyde $=8.039 \mathrm{~min} ; \mathrm{R}_{\mathrm{t}}$ branched aldehyde $=8.139 \mathrm{~min} .{ }^{1} \mathrm{H}$ NMR analysis allowed to establish the ratio between linear and branched compound $(85: 15)$.

11-(1,3-Dioxolan-2-yl)undecanal (23). The title compound was obtained following general method $A$, starting from 5 and using $10 \mathrm{~N} \mathrm{NaOH}$ during the work-up. Purification: 10\% EtAOc in petroleum ether. Yield: $72 \%$. GC/MS (m/z): 242; $R_{t}=20.425 \mathrm{~min}$ (Method A). ${ }^{1} \mathrm{H}$ NMR $\left(600 \mathrm{MHz}, \mathrm{CDCl}_{3}\right): \delta 9.76(\mathrm{~s}, 1 \mathrm{H}), 4.84(\mathrm{t}, J=$ $4.8 \mathrm{~Hz}, 1 \mathrm{H}), 3.96(\mathrm{t}, J=6.8 \mathrm{~Hz}, 2 \mathrm{H}), 3.84(\mathrm{t}, J=6.8 \mathrm{~Hz}, 2 \mathrm{H}), 2.41(\mathrm{t}, J=$ $7.2 \mathrm{~Hz}, 2 \mathrm{H}), 1.63(\mathrm{dp}, J=17.5,7.0,6.3 \mathrm{~Hz}, 2 \mathrm{H}), 1.41(\mathrm{p}, J=7.1 \mathrm{~Hz}, 2 \mathrm{H})$, 1.35-1.23 (m, 14H). ${ }^{13} \mathrm{C}$ NMR $\left(151 \mathrm{MHz}, \mathrm{CDCl}_{3}\right): \delta 203.0,104.7,64.8$, 43.9, 33.9, 29.5, 29.4 (2 C), 29.3 (2 C), 29.12, 24.1, 22.1. Elemental analysis calcd. for $\mathrm{C}_{14} \mathrm{H}_{26} \mathrm{O}_{3}: \mathrm{C}, 69.38 ; \mathrm{H}, 10.81 ; \mathrm{O}, 19.80$. Found: $\mathrm{C}_{1}$ $69.44 ; \mathrm{H}, 10.84$.

4-Oxobutyl acetate (24). The title compound was obtained following general method $A$, starting from allyl benzoate and using $4 \mathrm{~N} \mathrm{HCl}$ during the work-up. Yield: $81 \%$. GC/MS (m/z): 130; $\mathrm{R}_{\mathrm{t}}=$ $8.655 \mathrm{~min}$ (Method A). ${ }^{1} \mathrm{H}$ NMR $\left(600 \mathrm{MHz}, \mathrm{CDCl}_{3}\right): \delta 9.80(\mathrm{~s}, 1 \mathrm{H}), 4.11$ $(\mathrm{t}, J=6.2 \mathrm{~Hz}, 2 \mathrm{H}), 2.55(\mathrm{t}, J=6.9 \mathrm{~Hz}, 2 \mathrm{H}), 2.05(\mathrm{~s}, 3 \mathrm{H}), 1.98(\mathrm{q}, J=$ $6.4 \mathrm{~Hz}, 2 \mathrm{H}) .{ }^{3} \mathrm{C}$ NMR $\left(151 \mathrm{MHz}, \mathrm{CDCl}_{3}\right): \delta 201.2,171.0,63.4,40.5$, $21.3,20.9$. The spectral data were identical to those reported in the literature. ${ }^{[63]}$

4-(1,3-Dioxoisoindolin-2-yl)butanal (25). The title compound was obtained following general method $B$, starting from 7 and using $10 \mathrm{~N} \mathrm{NaOH}$ during the work-up. Yield: $83 \%$. GC/MS (m/z): $217 ; \mathrm{R}_{\mathrm{t}}=$ $21.046 \mathrm{~min}$ (Method A). ${ }^{1} \mathrm{H}$ NMR $\left(400 \mathrm{MHz}, \mathrm{CDCl}_{3}\right) \delta 9.77(\mathrm{~s}, 1 \mathrm{H})$, 7.87-7.83 (m, 2H), 7.74-7.71 (m, 2H), $3.74(\mathrm{t}, J=6.6 \mathrm{~Hz}, 2 \mathrm{H}), 2.54\left(\mathrm{t}_{\text {, }}\right.$ $J=6.8 \mathrm{~Hz}, 2 \mathrm{H}), 2.05-1.98(\mathrm{~m}, 2 \mathrm{H}) .{ }^{13} \mathrm{C}$ NMR $\left(101 \mathrm{MHz}, \mathrm{CDCl}_{3}\right) \delta 201.2$, $168.7,134.4,132.3,123.6,41.4,37.4,21.5$. The spectral data were identical to those reported in the literature. ${ }^{[64]}$

4-(3,4-Dimethoxyphenyl)butanal (26a). The title compound was obtained following general method $\mathrm{A}$, starting from 4-allyl-1,2dimethoxybenzene and using $10 \mathrm{~N} \mathrm{NaOH}$ during the work-up. Purification: $10 \%$ EtAOc in petroleum ether. Yield: $65 \%$. GC/MS (m/z): 208; $\mathrm{R}_{\mathrm{t}}=18.345 \mathrm{~min}$ (Method A). ${ }^{1} \mathrm{H}$ NMR $\left(600 \mathrm{MHz}, \mathrm{CDCl}_{3}\right): \delta$ $9.76(\mathrm{~s}, 1 \mathrm{H}), 6.80(\mathrm{~d}, J=7.9 \mathrm{~Hz}, 1 \mathrm{H}), 6.71(\mathrm{~d}, J=9.1 \mathrm{~Hz}, 1 \mathrm{H}), 6.70(\mathrm{~s}$, $1 \mathrm{H}), 3.88(\mathrm{~s}, 3 \mathrm{H}), 3.86(\mathrm{~s}, 3 \mathrm{H}), 2.61(\mathrm{t}, J=7.5 \mathrm{~Hz}, 2 \mathrm{H}), 2.61(\mathrm{t}, J=$ $7.5 \mathrm{~Hz}, 2 \mathrm{H}), 1.95(\mathrm{p}, J=7.3 \mathrm{~Hz}, 2 \mathrm{H}) .{ }^{13} \mathrm{C}$ NMR $\left(151 \mathrm{MHz}, \mathrm{CDCl}_{3}\right): \delta$ 202.4, 148.9, 147.4, 133.9, 120.3, 111.7, 111.3, 56.0, 43.1, 34.6, 23.8. Elemental analysis calcd. for $\mathrm{C}_{12} \mathrm{H}_{16} \mathrm{O}_{3}: \mathrm{C}, 69.21 ; \mathrm{H}, 7.74 ; \mathrm{O}, 23.05$. Found: $\mathrm{C}, 69.17 ; \mathrm{H}, 7.72$.

3-(3,4-Dimethoxyphenyl)-2-methylpropanal (26b). The title compound was obtained following general method $A$, starting from 4allyl-1,2-dimethoxybenzene and using $10 \mathrm{~N} \mathrm{NaOH}$ during the workup. Purification: $10 \%$ EtAOc in petroleum ether. Yield: $11 \%$. GC/MS (m/z): 208; $\mathrm{R}_{\mathrm{t}}=17.359 \mathrm{~min}$ (Method A). ${ }^{1} \mathrm{H}$ NMR $\left(600 \mathrm{MHz}, \mathrm{CDCl}_{3}\right): \delta$ $9.64(\mathrm{~s}, 1 \mathrm{H}), 6.87(\mathrm{~d}, J=6.5 \mathrm{~Hz}, 1 \mathrm{H}), 6.75(\mathrm{~d}, J=9.9 \mathrm{~Hz}, 1 \mathrm{H}), 6.66(\mathrm{~s}$, $1 \mathrm{H}), 3.90(\mathrm{~s}, 3 \mathrm{H}), 3.88(\mathrm{~s}, 3 \mathrm{H}), 2.13-2.04(\mathrm{~m}, 1 \mathrm{H}), 1.77-1.70(\mathrm{~m}, 1 \mathrm{H})$ $1.67(\mathrm{q}, J=8 \mathrm{~Hz}, 1 \mathrm{H}), 0.91(\mathrm{~s}, 3 \mathrm{H}) .{ }^{13} \mathrm{C}$ NMR $\left(151 \mathrm{MHz}, \mathrm{CDCl}_{3}\right): \delta$ $201.0121 .1,119.7,111.6,111.1,109.7,60.4,55.9,22.8,11.7,10.3$. Elemental analysis calcd. for $\mathrm{C}_{12} \mathrm{H}_{16} \mathrm{O}_{3}: \mathrm{C}, 69.21 ; \mathrm{H}, 7.74 ; \mathrm{O}, 23.05$ Found: $\mathrm{C}, 69.19 ; \mathrm{H}, 7.72$

3,4,5-Trimethoxy- $N$-(4-oxobutyl)benzamide (27a). The title compound was obtained following general method B, starting from 9 and using $10 \mathrm{~N} \mathrm{NaOH}$ during the work-up. Purification: $2 \% \mathrm{MeOH}$ in $\mathrm{CH}_{2} \mathrm{Cl}_{2}$. Yield: $60 \%$. ${ }^{1} \mathrm{H}$ NMR $\left(400 \mathrm{MHz}, \mathrm{CDCl}_{3}\right): \delta 9.79(\mathrm{~s}, 1 \mathrm{H}), 6.98$ $(\mathrm{s}, 2 \mathrm{H}), 3.87(\mathrm{~s}, 3 \mathrm{H}), 3.83(\mathrm{~s}, 6 \mathrm{H}), 3.44(\mathrm{t}, J=6.3 \mathrm{~Hz}, 2 \mathrm{H}), 2.61(\mathrm{t}, J=$ $6.6 \mathrm{~Hz}, 2 \mathrm{H}), 1.94(\mathrm{q}, J=6.7 \mathrm{~Hz}, 2 \mathrm{H}) .{ }^{13} \mathrm{C}$ NMR $\left(151 \mathrm{MHz}, \mathrm{CDCl}_{3}\right): \delta$ 200.0, 167.1, 153.3, 141.4, 129.1, 104.6, 60.9, 60.3, 56.3, 39.9, 23.2, 22.2. Elemental analysis calcd. for $\mathrm{C}_{14} \mathrm{H}_{19} \mathrm{NO}_{5}: \mathrm{C}, 59.78 ; \mathrm{H}, 6.81 ; \mathrm{N}$, 4.98; O, 28.44. Found: $C, 59.80 ; \mathrm{H}, 6.87 ; \mathrm{N}, 4.93$
3,4,5-Trimethoxy- $N$-(2-methyl-3-oxopropyl)benzamide (27 b). The title compound was obtained following general method $B$, starting from 9 and using $10 \mathrm{~N} \mathrm{NaOH}$ during the work-up. Purification: $2 \%$ $\mathrm{MeOH}$ in $\mathrm{CH}_{2} \mathrm{Cl}_{2}$. Yield: $9 \%$. ' $\mathrm{H}$ NMR $\left(600 \mathrm{MHz}, \mathrm{CDCl}_{3}\right): \delta 9.68(\mathrm{~s}, 1 \mathrm{H})$, 7.05 (s, 2H), $3.91(\mathrm{~s}, 6 \mathrm{H}), 3.88$ (s, 3H), 1.99 (ddt, $J=169.1,14.3,7.6 \mathrm{~Hz}$, 2H), $2.05-1.91(\mathrm{~m}, 1 \mathrm{H}), 1.02(\mathrm{~d}, J=7.4 \mathrm{~Hz}, 3 \mathrm{H}) .{ }^{13} \mathrm{C}$ NMR $(151 \mathrm{MHz}$ $\left.\mathrm{CDCl}_{3}\right): \delta 199.3,167.1,153.3,141.3129 .2,104.6,60.9,60.3,56.4$, 29.7, 14.1, 9.5. Elemental analysis calcd. for $\mathrm{C}_{14} \mathrm{H}_{19} \mathrm{NO}_{5}: \mathrm{C}, 59.78 ; \mathrm{H}$, $6.81 ; \mathrm{N}, 4.98 ; \mathrm{O}, 28.44$. Found: $\mathrm{C}, 59.83 ; \mathrm{H}, 6.84 ; \mathrm{N}, 4.90$.

2,4-Difluoro- $\mathrm{N}$-(4-oxobutyl)benzamide (28). The title compound was obtained following general method $A$, starting from 10 and using $10 \mathrm{~N} \mathrm{NaOH}$ during the work-up. Purification: $50 \%$ EtAOc in petroleum ether. Yield: $65 \%$. ${ }^{1} \mathrm{H}$ NMR $\left(600 \mathrm{MHz}, \mathrm{CDCl}_{3}\right): \delta 9.83(\mathrm{~s}$, $1 \mathrm{H}), 8.17-8.07(\mathrm{~m}, 1 \mathrm{H}), 7.47(\mathrm{q}, J=7.5 \mathrm{~Hz}, 1 \mathrm{H}), 6.92-6.85(\mathrm{~m}, 1 \mathrm{H})$, 6.77 (bs, 1H), $3.52(\mathrm{t}, J=6.5 \mathrm{~Hz}, 2 \mathrm{H}), 2.60(\mathrm{t}, J=7.0 \mathrm{~Hz}, 2 \mathrm{H}), 1.98(\mathrm{q}$ $J=7.1 \mathrm{~Hz}, 2 \mathrm{H}) .{ }^{13} \mathrm{C}$ NMR $\left(151 \mathrm{MHz}, \mathrm{CDCl}_{3}\right): \delta 202.0,151.9,133.8$, $130.7112 .5,112.0,104.6,104.1,39.5,23.4,22.0$. Elemental analysis calcd. for $\mathrm{C}_{11} \mathrm{H}_{11} \mathrm{~F}_{2} \mathrm{NO}_{2}$ : C, 58.15; $\mathrm{H}, 4.88 ; \mathrm{F}, 16.72 ; \mathrm{N}, 6.16 ; \mathrm{O}, 14.08$. Found: $\mathrm{C}, 58.20 ; \mathrm{H}, 4.93 ; \mathrm{N}, 6.17$.

4-(Benzyloxy)- $N$-(4-oxobutyl)benzamide (29). The title compound was obtained following general method $\mathrm{B}$, starting from 11 and using $10 \mathrm{~N} \mathrm{NaOH}$ during the work-up. Yield: $37 \%$. ${ }^{1} \mathrm{H}$ NMR $\left(600 \mathrm{MHz}, \mathrm{CDCl}_{3}\right): \delta 9.83(\mathrm{~s}, 1 \mathrm{H}), 7.74(\mathrm{~d}, J=8.0 \mathrm{~Hz}, 2 \mathrm{H}), 7.58(\mathrm{bs}, 1 \mathrm{H})$, 7.46-7.38 (m, 5H), $7.00(\mathrm{~d}, J=7.9 \mathrm{~Hz}, 2 \mathrm{H}), 5.12(\mathrm{~s}, 2 \mathrm{H}), 3.49(\mathrm{t}, J=$ $5.9 \mathrm{~Hz}, 2 \mathrm{H}), 2.63(\mathrm{t}, J=6.8 \mathrm{~Hz}, 2 \mathrm{H}), 1.98(\mathrm{q}, J=6.8 \mathrm{~Hz}, 2 \mathrm{H}) .{ }^{13} \mathrm{C}$ NMR $\left(151 \mathrm{MHz}, \mathrm{CDCl}_{3}\right): \delta 202.3,136.4,129.6,129.5,129.4,128.7,128.2$, $127.5,126.9,123.9,114.7,114.6,114.5,114.3,70.1,39.6,29.7,22.7$. Elemental analysis calcd. for $\mathrm{C}_{18} \mathrm{H}_{19} \mathrm{NO}_{3}: \mathrm{C}, 72.71 ; \mathrm{H}, 6.44 ; \mathrm{N}, 4.71 ; \mathrm{O}$, 16.14. Found: $\mathrm{C}, 72.66 ; \mathrm{H}, 6.48 ; \mathrm{N}, 4.78$.

$\mathrm{N}$-(4-Oxobutyl)benzamide (30 a). The title compound was obtained following general procedure $A$, starting from 12 and using $10 \mathrm{~N}$ $\mathrm{NaOH}$ during the work-up. Purification: $10 \%$ EtAOc in petroleum ether. Yield: $62 \%$. GC-MS (m/z): 191.2, $R_{t}=15.050 \mathrm{~min}$ (Method A). ${ }^{1} \mathrm{H}$ NMR $\left(400 \mathrm{MHz}_{1} \mathrm{CDCl}_{3}\right) \delta 9.42(\mathrm{~s}, 1 \mathrm{H}), 7.81(\mathrm{~d}, J=8.3 \mathrm{~Hz}, 2 \mathrm{H}), 7.72$ $(\mathrm{d}, J=8.4 \mathrm{~Hz}, 2 \mathrm{H}), 7.47(\mathrm{dd}, J=7.4,7.4 \mathrm{~Hz}, 1 \mathrm{H}), 7.44(\mathrm{dd}, J=7.4$, $7.4 \mathrm{~Hz}, 1 \mathrm{H}), 7.42$ (dd, $J=7.5,7.4 \mathrm{~Hz}, 2 \mathrm{H}), 7.34$ (dd, $J=7.8,7.7 \mathrm{~Hz}, 2 \mathrm{H})$ $6.70(\mathrm{bs}, 1 \mathrm{H}), 6.64(\mathrm{dd}, J=7.5,7.4 \mathrm{~Hz}, 1 \mathrm{H}), 6.44(\mathrm{bs}, 1 \mathrm{H}), 3.54(\mathrm{dd}, J=$ $6.5,6.5 \mathrm{~Hz}, 2 \mathrm{H}), 3.53(\mathrm{dd}, J=6.4,6.4 \mathrm{~Hz}, 2 \mathrm{H}), 2.65(\mathrm{dd}, J=6.0,6.0 \mathrm{~Hz}$, $2 \mathrm{H}), 2.59$ (dd, $J=7.5,7.5 \mathrm{~Hz}, 1 \mathrm{H}), 2.58(\mathrm{dd}, J=7.0,7.0 \mathrm{~Hz}, 1 \mathrm{H}), 1.92$ (ddd, $J=7.0,7.0,6.9 \mathrm{~Hz}, 2 \mathrm{H}), 1.44$ (bs, 2H). ${ }^{13} \mathrm{C}$ NMR $(101 \mathrm{MHz}$, $\left.\mathrm{CDCl}_{3}\right) \delta$ 202.1, 170.9, 167.6, 135.7, 134.3, 131.2, 130.3, 128.4, 128.3, $127.1,126.7,82.3,49.1,41.4,39.3,32.1,23.6,21.7$. The spectral data were identical to those reported in the literature. ${ }^{[65]}$

$\mathrm{N}$-(2-Methyl-3-oxopropyl)benzamide (30 b). The title compound was obtained following general procedure $A$, starting from 12 and using $10 \mathrm{~N} \mathrm{NaOH}$ during the work-up. Purification: $10 \%$ EtAOc in petroleum ether. Yield: $14 \%$. GC-MS $(\mathrm{m} / \mathrm{z}): 191.3, \mathrm{R}_{\mathrm{t}}=16.716 \mathrm{~min}$ (Method A). ${ }^{1} \mathrm{H}$ NMR $\left(400 \mathrm{MHz}, \mathrm{CDCl}_{3}\right): \delta 9.69(\mathrm{~s}, 1 \mathrm{H}), 7.70(\mathrm{~d}, J=$ $7.0 \mathrm{~Hz}, 2 \mathrm{H}), 7.45(\mathrm{~d}, J=7.3 \mathrm{~Hz}, 1 \mathrm{H}), 7.41-7.36(\mathrm{~m}, 2 \mathrm{H}), 3.78-3.43(\mathrm{~m}$, $2 \mathrm{H}), 2.77(\mathrm{td}, J=7.6,4.3 \mathrm{~Hz}, 1 \mathrm{H}), 1.19(\mathrm{~d}, J=7.5 \mathrm{~Hz}, 3 \mathrm{H}) .{ }^{13} \mathrm{C}$ NMR $\left(101 \mathrm{MHz}, \mathrm{CDCl}_{3}\right): \delta 204.4,167.6,134.2,131.6,128.6,126.9,46.8$, 39.8, $11.5 .^{[66]}$

4-((tert-Butyldimethylsilyl)oxy)butanal (33). The title compound was obtained following general method $A$, starting from 15 and using $10 \mathrm{~N} \mathrm{NaOH}$ during the work-up. Yield: $11 \%$. GC/MS (m/z):

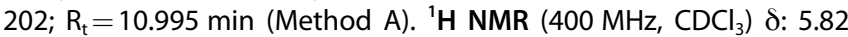
(ddt, $J=6.8,10.5,12.6 \mathrm{~Hz}, 1 \mathrm{H}), 5.05-4.92(\mathrm{~m}, 2 \mathrm{H}), 3.61(\mathrm{t}, J=6.8 \mathrm{~Hz}$, 2H), $2.12(\mathrm{~m}, 2 \mathrm{H}), 1.63-1.58(\mathrm{~m}, 2 \mathrm{H}), 0.90(\mathrm{~s}, 9 \mathrm{H}), 0.05(\mathrm{~s}, 6 \mathrm{H}) ;{ }^{13} \mathrm{C}$ NMR $\left(101 \mathrm{MHz}_{1} \mathrm{CDCl}_{3}\right) \delta: 138.8,114.6,62.7,32.1,30.2,26.1,18.5$, -5.1 . The spectral data were identical to those reported in the literature. ${ }^{[67]}$

12-((tert-Butyldimethylsilyl)oxy)dodecanal (34). The title compound was obtained following general method $A$, starting from 16 
and using $10 \mathrm{~N} \mathrm{NaOH}$ during the work-up. Yield: $81 \%$. GC/MS (m/z): 314; $\mathrm{Rt}=21.415 \mathrm{~min}$ (Method A). ${ }^{1} \mathrm{H}$ NMR $\left(400 \mathrm{MHz}, \mathrm{CDCl}_{3}\right) \delta=9.76$ $(\mathrm{t}, J=1.9 \mathrm{~Hz}, 1 \mathrm{H}), 3.59(\mathrm{t}, J=6.6 \mathrm{~Hz}, 2 \mathrm{H}), 2.41(\mathrm{td}, J=7.4,1.9 \mathrm{~Hz}, 2 \mathrm{H})$, $1.67-1.58(\mathrm{~m}, 2 \mathrm{H}), 1.52-1.47(\mathrm{~m}, 2 \mathrm{H}), 1.35-1.24(\mathrm{~m}, 14 \mathrm{H}), 0.89(\mathrm{~s}$ $9 \mathrm{H}), 0.05(\mathrm{~s}, 6 \mathrm{H}) .{ }^{13} \mathrm{C}$ NMR $\left(101 \mathrm{MHz}, \mathrm{CDCl}_{3}\right) \delta=203.0,63.4,44.0$, 33.0, 29.7, 29.6, 29.5 (3 C), 29.3, 26.1 (3 C), 25.9, 22.2, 18.5, -5.1 (2C). The spectral data were identical to those reported in the literature.

4-Oxobutyl benzoate (35). The title compound was obtained following general method $\mathrm{A}$, starting from 17 and using $4 \mathrm{~N} \mathrm{HCl}$ during the work-up. Yield: $61 \%$. The reaction was analyzed through ${ }^{1} \mathrm{H}$ NMR $(600 \mathrm{MHz}) .{ }^{1} \mathrm{H}$ NMR $\left(400 \mathrm{MHz}, \mathrm{CDCl}_{3}\right): \delta 9.81(\mathrm{~s}, 1 \mathrm{H}), 8.08(\mathrm{~d}$ $J=7.5 \mathrm{~Hz}, 2 \mathrm{H}), 7.58(\mathrm{t}, J=7.5 \mathrm{~Hz}, 1 \mathrm{H}), 7.44(\mathrm{t}, J=7.7 \mathrm{~Hz}, 2 \mathrm{H}), 4.34(\mathrm{t}$, $J=6.3 \mathrm{~Hz}, 2 \mathrm{H}), 2.61(\mathrm{t}, J=7.1 \mathrm{~Hz}, 2 \mathrm{H}), 2.09(\mathrm{q}, J=6.8 \mathrm{~Hz}, 2 \mathrm{H}) .{ }^{13} \mathrm{C}$ NMR $\left(151 \mathrm{MHz}, \mathrm{CDCl}_{3}\right): \delta 194.5,157.6,133.7,133.1,130.2,129.6$, $128.5,128.4,63.9,40.6,29.7$. The spectral data were identical to those reported in the literature. ${ }^{[65]}$

2-Phenylpropanal (36a). The title compound was obtained following general procedure $A$, starting from 12 and using $10 \mathrm{~N} \mathrm{NaOH}$ during the work-up. Purification: $10 \%$ EtAOc in petroleum ether. Yield: $57 \%$. GC-MS (m/z): 134.5, $\mathrm{R}_{\mathrm{t}}=10.405 \mathrm{~min}$ (Method A). ${ }^{1} \mathrm{H}$ NMR $\left(400 \mathrm{MHz}, \mathrm{CDCl}_{3}\right) \delta 9.72(\mathrm{~d}, J=1.4 \mathrm{~Hz}, 1 \mathrm{H}), 7.44-7.37(\mathrm{~m}, 2 \mathrm{H})$, $7.30(\mathrm{tt}, J=7.4,2.1 \mathrm{~Hz}, 1 \mathrm{H}), 7.24-7.18(\mathrm{~m}, 2 \mathrm{H}), 3.65(\mathrm{qd}, J=7.2$, $0.8 \mathrm{~Hz}, 1 \mathrm{H}), 1.41(\mathrm{~d}, J=7.1 \mathrm{~Hz}, 3 \mathrm{H}) .{ }^{13} \mathrm{C}$ NMR $\left(101 \mathrm{MHz}, \mathrm{CDCl}_{3}\right) \delta$ 201.2, 137.9, 129.2, 128.4, 127.7, 53.1, 14.7 .

3-Phenylpropanal (36 b). The title compound was obtained following general procedure $A$, starting from 12 and using $10 \mathrm{~N} \mathrm{NaOH}$ during the work-up. Purification: $10 \%$ EtAOc in petroleum ether Yield: $19 \%$. GC-MS (m/z): 134.4, $\mathrm{R}_{\mathrm{t}}=11.527 \mathrm{~min}$ (Method A). ${ }^{1} \mathrm{H}$ NMR $\left(400 \mathrm{MHz}, \mathrm{CDCl}_{3}\right) \delta 9.80(\mathrm{~s}, 1 \mathrm{H}), 7.28-7.23(\mathrm{~m}, 2 \mathrm{H}), 7.21-7.17(\mathrm{t}$ $\mathrm{J}=8.1 \mathrm{~Hz}, 3 \mathrm{H}), 2.88(\mathrm{t}, J=7.54 \mathrm{~Hz}, 2 \mathrm{H}), 2.75(\mathrm{t}, J=7.3 \mathrm{~Hz}, 2 \mathrm{H}) .{ }^{13} \mathrm{C}$ NMR $\left(101 \mathrm{MHz}, \mathrm{CDCl}_{3}\right) \delta 201.6,140.6,128.7,128.5,126.3,45.7,28.2$.

(8R)-8-(6-Methoxyquinolin-4-yl)-7-oxa-1-azatricyclo[7.4.0.0 $\left.{ }^{[3,11]}\right]$ tridecan-6-ol (37). The title compound was obtained following general method $B$, starting from quinine 19 and using $10 \mathrm{~N} \mathrm{NaOH}$ during the work-up. Yield: $53 \%$. ${ }^{1} \mathrm{H}$ NMR $\left(600 \mathrm{MHz}, \mathrm{CD}_{3} \mathrm{OD}\right): \delta 8.63$ $(d, J=4.5 \mathrm{~Hz}, 1 \mathrm{H}), 7.91(\mathrm{~d}, J=9.0 \mathrm{~Hz}, 1 \mathrm{H}), 7.65(\mathrm{~d}, J=4.4 \mathrm{~Hz}, 1 \mathrm{H})$, $7.40(\mathrm{~s}, 1 \mathrm{H}), 7.38(\mathrm{~d}, J=7.5 \mathrm{~Hz}, 1 \mathrm{H}), 5.59(\mathrm{~d}, J=7.4 \mathrm{~Hz}, 1 \mathrm{H}), 4.35(\mathrm{t}$, $J=6.91 \mathrm{~Hz}, 1 \mathrm{H}), 3.94(\mathrm{~s}, 3 \mathrm{H}), 3.10(\mathrm{dq}, J=13.0,9.3,7.0 \mathrm{~Hz}, 2 \mathrm{H}), 2.73-$ $2.62(\mathrm{~m}, 1 \mathrm{H}), 2.45-2.35(\mathrm{~m}, 2 \mathrm{H}), 1.86(\mathrm{ddd}, J=26.4,12.6,7.2 \mathrm{~Hz}, 2 \mathrm{H})$, $1.59(\mathrm{~d}, J=8.2 \mathrm{~Hz}, 1 \mathrm{H}), 1.53-1.37(\mathrm{~m}, 4 \mathrm{H}), 1.27(\mathrm{dt}, J=11.0,5.8 \mathrm{~Hz}$ $3 \mathrm{H}) .{ }^{13} \mathrm{C}$ NMR (151 MHz, $\left.\mathrm{CD}_{3} \mathrm{OD}\right): \delta 158.4,149.1,146.8,143.4,130.0$, $126.7,122.0,118.7,101.1,98.4,70.7,59.5,57.9,55.1,42.8,35.0,34.4$, $29.3,27.2,25.8,19.9$

5-Methyl-5-(4-methylpent-3-en-1-yl)tetrahydrofuran-2-ol (38). The title compound was obtained following general method $A$, starting from linalool 20 and using $10 \mathrm{~N} \mathrm{NaOH}$ during the work-up. Yield: $78 \%$. GC/MS (m/z): 184; $R_{t}=13.887$ min (Method A). ' $H$ NMR $\left(600 \mathrm{MHz}, \mathrm{CDCl}_{3}\right): \delta 5.49(\mathrm{bs}, 1 \mathrm{H}), 5.40(\mathrm{t}, J=6.9 \mathrm{~Hz}, 1 \mathrm{H}), 5.11(\mathrm{t}, J=$ $7.0 \mathrm{~Hz}, 1 \mathrm{H}), 3.64(\mathrm{~s}, 3 \mathrm{H}), 2.10-1.95(\mathrm{~m}, 4 \mathrm{H}), 1.91(\mathrm{dq}, J=17.1,7.2$, $5.8 \mathrm{~Hz}, 2 \mathrm{H}), 1.68(\mathrm{~s}, 3 \mathrm{H}), 1.61(\mathrm{~s}, 3 \mathrm{H}), 1.46(\mathrm{ddt}, J=10.6,7.2,4.2 \mathrm{~Hz}$ $2 \mathrm{H}) .{ }^{13} \mathrm{C}$ NMR $\left(151 \mathrm{MHz}, \mathrm{CDCl}_{3}\right): \delta 124.6,99.9,84.2,70.6,42.8,41.9$, 34.8, 28.2, 25.7, 23.6, 17.6. Elemental analysis calcd. for $\mathrm{C}_{11} \mathrm{H}_{20} \mathrm{O}_{2}: \mathrm{C}$, 71.70; $\mathrm{H}, 10.94 ; \mathrm{O}, 17.36$. Found: $\mathrm{C}, 71.75 ; \mathrm{H}, 10.89$.

\section{General methods for the synthesis of cyclic hemiacetals}

The following hemiacetalic compounds were all synthesized following general method $A$, using $10 \mathrm{~N} \mathrm{NaOH}$ in the work-up. The crude compounds were purified by means of chromatography on silica gel eluting with a very slow $5-75 \%$ gradient of EtAOc in petroleum ether, if not otherwise specified. The yields are referred to the isolated 6-membered hemiacetals, obtained as $1: 1$ diaster- eoisomeric mixtures. The branched products, leading to the substituted 5-membered hemiacetals, were not isolated from the crude materials.

6-(4-Bromophenyl)tetrahydro-2H-pyran-2-ol (40 a). Prepared starting from allylalcohol 39 a. Yield: $40 \%$. GC/MS (m/z): 256.8-258.2 ( $\mathrm{Br}$ isotopes), $\mathrm{R}_{\mathrm{t}}=20.251 \mathrm{~min}$ (Method A). ${ }^{1} \mathrm{H}$ NMR $\left(400 \mathrm{MHz}, \mathrm{CDCl}_{3}\right) \delta$ $7.43(\mathrm{dd}, J=8.4,2.2 \mathrm{~Hz}, 4 \mathrm{H}), 7.22$ (dd, $J=8.6,2.1 \mathrm{~Hz}, 4 \mathrm{H}$ ), 5.42 (s, $1 \mathrm{H}), 4.95(\mathrm{~d}, J=11.5 \mathrm{~Hz}, 1 \mathrm{H}), 4.88-4.78(\mathrm{~m}, 1 \mathrm{H}), 4.43(\mathrm{~d}, J=11.1 \mathrm{~Hz}$, $1 \mathrm{H}), 2.90(\mathrm{~d}, J=5.9 \mathrm{~Hz}, 1 \mathrm{H}), 2.51(\mathrm{~s}, 1 \mathrm{H}), 2.06-1.99(\mathrm{~m}, 1 \mathrm{H}), 1.93(\mathrm{~d}$, $J=11.4 \mathrm{~Hz}, 2 \mathrm{H}), 1.83-1.61(\mathrm{~m}, 4 \mathrm{H}), 1.58-1.49(\mathrm{~m}, 3 \mathrm{H}), 1.48-1.34(\mathrm{~m}$, 2H). ${ }^{13} \mathrm{C}$ NMR $\left(101 \mathrm{MHz}, \mathrm{CDCl}_{3}\right) \delta 142.1,141.1,131.4,127.8,127.7$, 121.3, 121.1, 97.0, 92.4, 70.5, 33.7, 32.7, 32.4, 29.4, 22.4, 17.8. Elemental analysis calcd. for $\mathrm{C}_{11} \mathrm{H}_{13} \mathrm{BrO}_{2}: \mathrm{C}, 51.38 ; \mathrm{H}, 5.10 ; \mathrm{Br}, 31.08$; $\mathrm{O}, 12.44$. Found: $\mathrm{C}, 51.39 ; \mathrm{H}, 5.10$.

4-(6-Hydroxytetrahydro-2H-pyran-2-yl)benzonitrile (40 b). Prepared starting from allylalcohol $39 \mathrm{~b}$. Yield: $57 \%$. GC/MS (m/z): 203.6, $\mathrm{R}_{\mathrm{t}}=20.845 \mathrm{~min}$ (Method A). ${ }^{1} \mathrm{H}$ NMR $\left(400 \mathrm{MHz}, \mathrm{CDCl}_{3}\right) \delta 7.56$ (dd, $J=8.1,3.0 \mathrm{~Hz}, 4 \mathrm{H}), 7.41$ (dd, $J=13.9,8.1 \mathrm{~Hz}, 4 \mathrm{H}), 5.40(\mathrm{~s}, 1 \mathrm{H})$, $5.02(\mathrm{~d}, J=11.6 \mathrm{~Hz}, 1 \mathrm{H}), 4.83(\mathrm{~d}, J=9.2 \mathrm{~Hz}, 1 \mathrm{H}), 4.48(\mathrm{~d}, J=11.1 \mathrm{~Hz}$ $1 \mathrm{H}), 3.61(\mathrm{bs}, 1 \mathrm{H}), 3.17(\mathrm{bs}, 1 \mathrm{H}), 2.15-1.98(\mathrm{~m}, 1 \mathrm{H}), 1.91(\mathrm{t}, J=$ $11.6 \mathrm{~Hz}, 2 \mathrm{H}), 1.86-1.56(\mathrm{~m}, 5 \mathrm{H}), 1.56-1.30(\mathrm{~m}, 4 \mathrm{H}) .{ }^{13} \mathrm{C}$ NMR $\left(101 \mathrm{MHz}, \mathrm{CDCl}_{3}\right) \delta 148.5,147.4,132.2,126.8,126.6,126.5,126.2$, $118.9,111.1,110.9,96.9,92.3,70.3,33.7,32.7,32.2,29.4,22.4,17.7$. The spectral data were identical to those reported in the literature. ${ }^{[68]}$

6-(4-(tert-Butyl)phenyl)tetrahydro-2H-pyran-2-ol (40c). Prepared starting from allylalcohol 39 c. Yield: $82 \%$. GC-MS (m/z): 234.7, $\mathrm{R}_{\mathrm{t}}=$ $20.368 \mathrm{~min}$ (Method B). ' ${ }^{1} \mathrm{H}$ NMR $\left(600 \mathrm{MHz}, \mathrm{CDCl}_{3}\right) \delta 7.38$ (dd, $J=8.3$ $2.4 \mathrm{~Hz}, 4 \mathrm{H}), 7.35-7.28(\mathrm{~m}, 4 \mathrm{H}), 5.44(\mathrm{~s}, 1 \mathrm{H}), 5.01(\mathrm{~d}, J=11.3 \mathrm{~Hz}, 1 \mathrm{H})$, $4.86(\mathrm{~d}, J=9.5 \mathrm{~Hz}, 1 \mathrm{H}), 4.46(\mathrm{~d}, J=11.2 \mathrm{~Hz}, 1 \mathrm{H}), 3.33(\mathrm{bs}, 1 \mathrm{H}), 2.88$ (bs, 1H), 2.11-2.01 (m, 1H), $1.94(\mathrm{t}, J=15.7 \mathrm{~Hz}, 2 \mathrm{H}), 1.85(\mathrm{~d}, J=$ $13.0 \mathrm{~Hz}, 1 \mathrm{H}), 1.80-1.73(\mathrm{~m}, 2 \mathrm{H}), 1.73-1.62(\mathrm{~m}, 4 \mathrm{H}), 1.55(\mathrm{qd}, J=13.0$, $3.7 \mathrm{~Hz}, 1 \mathrm{H}), 1.48-1.38(\mathrm{~m}, 1 \mathrm{H}), 1.32(\mathrm{~s}, 18 \mathrm{H}) .{ }^{13} \mathrm{C}$ NMR $(151 \mathrm{MHz}$, $\left.\mathrm{CDCl}_{3}\right) \delta 143.7,141.4,126.2,125.9,125.8,125.3,125.2,125.0,96.9$, $94.4,71.2,34.5,33.1,32.7,31.5,29.6,28.69,22.4,17.8$. Elemental analysis calcd. for $\mathrm{C}_{15} \mathrm{H}_{22} \mathrm{O}_{2}: \mathrm{C}, 76.88 ; \mathrm{H}, 9.46 ; \mathrm{O}, 13.65$. Found: $\mathrm{C}$, $76.89 ; \mathrm{H}, 9.48$.

6-(4-Ethylphenyl)tetrahydro-2H-pyran-2-ol $(40 \mathrm{~d})$. Prepared starting from allylalcohol 39d. Yield: $73 \%$. GC-MS (m/z): 206.5, $R_{t}=$ $18.824 \mathrm{~min}$ (Method B). ${ }^{1} \mathrm{H}$ NMR $\left(600 \mathrm{MHz}_{1} \mathrm{CDCl}_{3}\right) \delta{ }^{1} \mathrm{H} \quad \mathrm{NMR}$ $\left(600 \mathrm{MHz}, \mathrm{CDCl}_{3}\right) \delta 7.28(\mathrm{dd}, J=12.8,6.0 \mathrm{~Hz}, 4 \mathrm{H}), 7.22-7.14(\mathrm{~m}, 4 \mathrm{H})$, $5.47(\mathrm{~s}, 1 \mathrm{H}), 4.93(\mathrm{~d}, J=9.3 \mathrm{~Hz}, 1 \mathrm{H}), 4.81(\mathrm{~d}, J=11.3 \mathrm{~Hz}, 1 \mathrm{H}), 4.44(\mathrm{~d}$, $J=11.0 \mathrm{~Hz}, 1 \mathrm{H}), 3.11-3.00(\mathrm{~m}, 1 \mathrm{H}), 2.72(\mathrm{dd}, J=15.0,7.4 \mathrm{~Hz}, 1 \mathrm{H})$ $2.65(\mathrm{q}, J=6.8 \mathrm{~Hz}, 2 \mathrm{H}), 2.13-2.05(\mathrm{~m}, 2 \mathrm{H}), 1.97(\mathrm{~d}, J=10.1 \mathrm{~Hz}, 2 \mathrm{H})$, $1.92-1.59(\mathrm{~m}, 6 \mathrm{H}), 1.59-1.41(\mathrm{~m}, 2 \mathrm{H}), 1.24(\mathrm{t}, J=7.7 \mathrm{~Hz}, 3 \mathrm{H}) .{ }^{13} \mathrm{C}$ NMR $\left(151 \mathrm{MHz}, \mathrm{CDCl}_{3}\right) \delta 143.6,141.3,129.1,128.2,127.9$ (2 C), 125.9, 125.3, 97.6, 93.1, 70.9, 33.7, 32.7, 29.4, 28.6, 22.4, 17.7. Elemental analysis calcd. for $\mathrm{C}_{13} \mathrm{H}_{18} \mathrm{O}_{2}: \mathrm{C}, 75.69 ; \mathrm{H}, 8.80 ; \mathrm{O}, 15.51$. Found: $\mathrm{C}$, 75.68; $\mathrm{H}, 8.78$.

6-(4-Fluorophenyl)tetrahydro-2H-pyran-2-ol (40 e). Prepared starting from allylalcohol 39e. Yield: $85 \%$. GC/MS (m/z): 196.3, $R_{\mathrm{t}}=$ $16.523 \mathrm{~min}$ (Method A). ${ }^{1} \mathrm{H}$ NMR $\left(400 \mathrm{MHz}, \mathrm{CDCl}_{3}\right) \delta 7.30(\mathrm{dt}, J=8.9$ $8.0 \mathrm{~Hz}, 4 \mathrm{H}), 6.99(\mathrm{t}, J=7.8 \mathrm{~Hz}, 4 \mathrm{H}), 5.42(\mathrm{~s}, 1 \mathrm{H}), 4.97(\mathrm{~d}, J=11.6 \mathrm{~Hz}$, $1 \mathrm{H}), 4.85(\mathrm{dd}, J=8.4,6.9 \mathrm{~Hz}, 1 \mathrm{H}), 4.44(\mathrm{~d}, J=11.3 \mathrm{~Hz}, 1 \mathrm{H}), 3.02(\mathrm{~d}$ $J=5.9 \mathrm{~Hz}, 1 \mathrm{H}), 2.62(\mathrm{~s}, 1 \mathrm{H}), 2.01(\mathrm{t}, J=12.1 \mathrm{~Hz}, 1 \mathrm{H}), 1.98-1.85(\mathrm{~m}$, $2 \mathrm{H}), 1.84-1.62(\mathrm{~m}, 6 \mathrm{H}), 1.51-1.31(\mathrm{~m}, 3 \mathrm{H}) .{ }^{13} \mathrm{C}$ NMR $\left(151 \mathrm{MHz}, \mathrm{CDCl}_{3}\right)$ d $162.9,161.3,138.8,137.9,127.8,127.7,127.6,115.2,115.1,96.9$, 92.4, 77.9, 70.5, 33.8, 32.8, 32.3, 29.4, 22.4, 17.8. Elemental analysis calcd. for $\mathrm{C}_{11} \mathrm{H}_{13} \mathrm{FO}_{2}: \mathrm{C}, 67.33 ; \mathrm{H}, 6.68 ; \mathrm{F}, 9.68 ; \mathrm{O}, 16.31$. Found: $\mathrm{C}$, 67.40; $\mathrm{H}, 6.73$.

6-(4-Nitrophenyl)tetrahydro-2H-pyran-2-ol (40 f). Prepared starting from allylalcohol 39f. Yield: $41 \%$ GC/MS (m/z): $223.6 \quad R_{t}=$ $19.357 \mathrm{~min}$ (Method A). ${ }^{1} \mathrm{H}$ NMR $\left(400 \mathrm{MHz}, \mathrm{CDCl}_{3}\right) \delta 8.22-8.16(\mathrm{~m}$ 
4H), 7.60-7.45 (m, 4H), $5.50(\mathrm{~s}, 1 \mathrm{H}), 5.13(\mathrm{dd}, J=12,2.4 \mathrm{~Hz}, 1 \mathrm{H})$ 4.95-4.90 (m, 1H), $4.61(\mathrm{dd}, J=11.4,2.2 \mathrm{~Hz}, 1 \mathrm{H}), 3.02(\mathrm{bs}, 1 \mathrm{H}), 2.62$ (bs, 1H), 1.38-1.62 (m, 2H), 1.66-2.20 (m, 4H), 2.12-1.92 (m, 2H), 1.91-1.72 (m, 6H), 1.58-1.41 (m, 4H). ${ }^{13} \mathrm{C}$ NMR $\left(101 \mathrm{MHz}, \mathrm{CDCl}_{3}\right) \delta$ 150.4, 149.2, 147.1, 147.0, 126.5, 123.5, 96.9, 92.2, 70.1, 33.8, 32.8, $32.1,29.3,22.3,17.6$. The spectral data were identical to those reported in the literature. ${ }^{[69]}$

6-Phenyltetrahydro- $2 \mathrm{H}$-pyran-2-ol $(\mathbf{4 0} \mathrm{g})$. Prepared starting from allylalcohol $39 \mathrm{~g}$. Yield: $51 \%$. GC/MS (m/z): $178.5, \mathrm{R}_{\mathrm{t}}=16.457 \mathrm{~min}$ (Method B). 'H NMR $\left(600 \mathrm{MHz}, \mathrm{CDCl}_{3}\right): \delta 7.38-7.26(\mathrm{~m}, 10 \mathrm{H}), 5.44(\mathrm{~s}$, $1 \mathrm{H}), 5.02(\mathrm{dd}, J=12.0,2.0 \mathrm{~Hz}, 1 \mathrm{H}), 4.88-4.85(\mathrm{~m}, 1 \mathrm{H}), 4.48(\mathrm{~d}, J=$ $11.5,1 \mathrm{H}), 3.29(\mathrm{~s}, 1 \mathrm{H}), 2.84$ (bs, 1H), 2.08-1.39 (m, 12H); ${ }^{13} \mathrm{C}$ NMR $\left(151 \mathrm{MHz}, \mathrm{CDCl}_{3}\right): \delta 142.9,142.0,128.3,127.5,127.4,126.0,125.9$, $96.9,92.4,78.6,71.1,33.6,32.7,32.3,29.4,22.5,17.9$. The spectral data were identical to those reported in the literature. ${ }^{[69]}$

6-(2-Fluorophenyl)tetrahydro-2H-pyran-2-ol $(40 \mathrm{~h})$. Prepared starting from allylalcohol $39 \mathrm{~h}$. Yield: $76 \%$. GC/MS (m/z): 196.4, $\mathrm{R}_{\mathrm{t}}=$ $16.242 \mathrm{~min}$ (Method A). ${ }^{1} \mathrm{H}$ NMR $\left(400 \mathrm{MHz}, \mathrm{CDCl}_{3}\right) \delta 7.48(\mathrm{dt}, J=$ $30.3,7.5 \mathrm{~Hz}, 2 \mathrm{H}), 7.25-7.15(\mathrm{~m}, 2 \mathrm{H}), 7.10(\mathrm{td}, J=6.9,4.4 \mathrm{~Hz}, 2 \mathrm{H})$, 7.03-6.93 (m, 2H), $5.41(\mathrm{~s}, 1 \mathrm{H}), 5.35(\mathrm{~d}, J=11.6 \mathrm{~Hz}, 1 \mathrm{H}), 4.87-4.80(\mathrm{~m}$, $1 \mathrm{H}), 4.77(\mathrm{~d}, J=11.2 \mathrm{~Hz}, 1 \mathrm{H}), 3.57(\mathrm{~d}, J=5.7 \mathrm{~Hz}, 1 \mathrm{H}), 3.07(\mathrm{~s}, 1 \mathrm{H})$, 2.08-2.02 (m, 1H), 1.94-1.84 (m, 3H), $1.65(\mathrm{~m}, 4 \mathrm{H}), 1.55(\mathrm{dd}, J=11.8$, $3.6 \mathrm{~Hz}, 1 \mathrm{H}), 1.48-1.35(\mathrm{~m}, 3 \mathrm{H}) .{ }^{13} \mathrm{C}$ NMR $\left(151 \mathrm{MHz}, \mathrm{CDCl}_{3}\right) \delta 160.6$, $158.5,130.1,129.8,128.8,128.7,127.4,124.3,123.9,115.2,115.1$, 102.0, 97.7, 97.1, 93.1, 92.5, 71.8, 64.8, 32.4, 32.4, 31.8, 31.7, 29.7, 29.6, 29.5, 29.3, 22.7, 22.5, 18.4, 17.8. Elemental analysis calcd. for $\mathrm{C}_{11} \mathrm{H}_{13} \mathrm{FO}_{2}: \mathrm{C}, 67.33 ; \mathrm{H}, 6.68 ; \mathrm{F}, 9.68 ; \mathrm{O}, 16.31$. Found: $\mathrm{C}, 67.37 ; \mathrm{H}$, 6.70 .

1-(3-Phenoxyphenyl)tetrahydro-2H-pyran-2-ol (40 i). Prepared starting from allylalcohol 39i. Yield: $78 \%$. GC-MS (m/z): 270.0, $R_{t}=$ $22.205 \mathrm{~min}$ (Method B). ${ }^{1} \mathrm{H}$ NMR $\left(600 \mathrm{MHz}, \mathrm{CDCl}_{3}\right) \delta$ 7.37-7.24 (m, $6 \mathrm{H}), 7.16-6.98(\mathrm{~m}, 10 \mathrm{H}), 6.98-6.85(\mathrm{~m}, 2 \mathrm{H}), 5.46(\mathrm{~s}, 1 \mathrm{H}), 4.94(\mathrm{~d}, J=$ $9.4 \mathrm{~Hz}, 1 \mathrm{H}), 4.80(\mathrm{~d}, J=10.4 \mathrm{~Hz}, 1 \mathrm{H}), 4.43(\mathrm{~d}, J=11.1 \mathrm{~Hz}, 1 \mathrm{H}), 3.76(\mathrm{~s}$, $1 \mathrm{H}), 2.55(\mathrm{bs}, 1 \mathrm{H}), 2.12-2.00(\mathrm{~m}, 2 \mathrm{H}), 1.96(\mathrm{~s}, 2 \mathrm{H}), 1.91-1.55(\mathrm{~m}, 6 \mathrm{H})$ $1.55-1.38(\mathrm{~m}, 2 \mathrm{H}) .{ }^{13} \mathrm{C}$ NMR $\left(151 \mathrm{MHz}, \mathrm{CDCl}_{3}\right) \delta 145.4,144.4,129.7$, $123.2,123.1,120.9,119.0,118.8,117.8,117.8,117.7,116.8,97.6$ $94.2,71.133 .3,32.6,31.0,29.5,22.7,18.2$. Elemental analysis calcd. for $\mathrm{C}_{17} \mathrm{H}_{18} \mathrm{O}_{32}: \mathrm{C}, 75.53 ; \mathrm{H}, 6.71 ; \mathrm{O}, 17.76$. Found: $\mathrm{C}, 75.52 ; \mathrm{H}, 6.67$.

6-(3-(Benzyloxy)phenyl)tetrahydro-2H-pyran-2-ol (40 j). Prepared starting from allylalcohol $39 \mathrm{j}$. Yield: $70 \%$ GC-MS (m/z): $284.5 \mathrm{R}_{\mathrm{t}}=$ 25.353 min (Method B). ${ }^{1} \mathrm{H}$ NMR $\left(600 \mathrm{MHz}, \mathrm{CDCl}_{3}\right)$ \& 7.47-7.43 (m, $4 \mathrm{H}), 7.39(\mathrm{t}, J=7.5 \mathrm{~Hz}, 4 \mathrm{H}), 7.34(\mathrm{~d}, J=7.2 \mathrm{~Hz}, 2 \mathrm{H}), 7.28-7.24(\mathrm{~m}, 2 \mathrm{H})$, $7.07(\mathrm{~s}, 1 \mathrm{H}), 7.04(\mathrm{~s}, 1 \mathrm{H}), 6.99-6.95(\mathrm{~m}, 2 \mathrm{H}), 6.89(\mathrm{dd}, J=6.7,3.7 \mathrm{~Hz}$, $2 \mathrm{H}), 5.47(\mathrm{~s}, 1 \mathrm{H}), 5.08(\mathrm{~s}, 4 \mathrm{H}), 5.01(\mathrm{~d}, J=10.2 \mathrm{~Hz}, 1 \mathrm{H}), 4.90(\mathrm{~d}, J=$ $8.2 \mathrm{~Hz}, 1 \mathrm{H}), 4.49(\mathrm{~d}, J=10.0 \mathrm{~Hz}, 1 \mathrm{H}), 2.95(\mathrm{bs}, 1 \mathrm{H}), 2.58(\mathrm{bs}, 1 \mathrm{H})$, $2.11-2.03(\mathrm{~m}, 2 \mathrm{H}), 1.97(\mathrm{~d}, J=9.2 \mathrm{~Hz}, 2 \mathrm{H}), 1.89-1.67(\mathrm{~m}, 4 \mathrm{H}), 1.62$ (dd, $J=13.2,3.5 \mathrm{~Hz}, 2 \mathrm{H}), 1.52(\mathrm{dd}, J=12.8,3.4 \mathrm{~Hz}, 1 \mathrm{H}), 1.49-1.39(\mathrm{~m}$ 1H). ${ }^{13} \mathrm{C}$ NMR $\left(151 \mathrm{MHz}, \mathrm{CDCl}_{3}\right) \delta 143.2,142.1,129.4,128.6,127.9$, 127.6, 127.5, 118.7, 118.6, 113.9, 113.7, 112.8, 112.5, 97.5, 94.2, 70.0 $33.6,32.7,31.1,29.4,22.3,18.3$. Elemental analysis calcd. for $\mathrm{C}_{18} \mathrm{H}_{20} \mathrm{O}_{3}: \mathrm{C}, 76.03 ; \mathrm{H}, 7.09 ; \mathrm{O}, 16.88$. Found: $\mathrm{C}, 76.07 ; \mathrm{H}, 7.12$.

6-(2,3,4-Trimethoxyphenyl)tetrahydro-2H-pyran-2-ol (40k). Prepared starting from allylalcohol $39 \mathrm{k}$. Yield: $40 \%$. GC-MS $(\mathrm{m} / \mathrm{z})$ : 267.9, $\mathrm{R}_{\mathrm{t}}=20.540 \mathrm{~min}$ (Method B). ${ }^{1} \mathrm{H}$ NMR $\left(600 \mathrm{MHz}, \mathrm{CDCl}_{3}\right) \delta 7.18$ $(\mathrm{d}, J=8.7 \mathrm{~Hz}, 1 \mathrm{H}), 7.11(\mathrm{~d}, J=8.6 \mathrm{~Hz}, 1 \mathrm{H}), 6.69(\mathrm{~d}, J=8.6 \mathrm{~Hz}, 2 \mathrm{H})$, $5.43(\mathrm{~s}, 1 \mathrm{H}), 5.31(\mathrm{~d}, J=11.6 \mathrm{~Hz}, 1 \mathrm{H}), 4.89(\mathrm{~d}, J=9.3 \mathrm{~Hz}, 1 \mathrm{H}), 4.76(\mathrm{~d}$, $J=11.0 \mathrm{~Hz}, 1 \mathrm{H}), 3.89(\mathrm{~s}, 6 \mathrm{H}), 3.85(\mathrm{~d}, J=4.7 \mathrm{~Hz}, 12 \mathrm{H}), 3.28(\mathrm{bs}, 1 \mathrm{H})$, $2.85(\mathrm{bs}, 1 \mathrm{H}), 2.11-2.05(\mathrm{~m}, 1 \mathrm{H}), 1.93(\mathrm{~d}, J=11.1 \mathrm{~Hz}, 2 \mathrm{H}), 1.85(\mathrm{~s}, 2 \mathrm{H})$, $1.83-1.65(\mathrm{~m}, 3 \mathrm{H}), 1.65-1.53(\mathrm{~m}, 2 \mathrm{H}), 1.51-1.37(\mathrm{~m}, 2 \mathrm{H}) .{ }^{13} \mathrm{C}$ NMR $\left(151 \mathrm{MHz}, \mathrm{CDCl}_{3}\right) \delta 141.9,141.7,129.1,128.9,128.6,127.6,125.3$, $121.5,121.3,107.6,107.5,97.7,93.2,72.5,65.2,60.7,56.0,32.6,31.2$, 29.6, 25.9, 23.0, 18.7. Elemental analysis calcd. for $\mathrm{C}_{14} \mathrm{H}_{20} \mathrm{O}: \mathrm{C}, 62.67$; $H, 7.51 ; O, 29.81$. Found: $C, 62.66 ; H, 7.46$.
1-(3,4-Dichlorophenyl)tetrahydro-2H-pyran-2-ol (40 I). Prepared starting from allylalcohol 39l. Yield: $25 \%$. GC/MS (m/z): 246.0 (246.9) -247.6 (248.5) (Cl isotopes), $\mathrm{R}_{\mathrm{t}}=18.550 \mathrm{~min}$ (Method B). ${ }^{1} \mathrm{H}$ NMR $\left(600 \mathrm{MHz}, \mathrm{CDCl}_{3}\right) \delta 7.47(\mathrm{~d}, J=22.1 \mathrm{~Hz}, 2 \mathrm{H}), 7.42-7.36(\mathrm{~m}, 2 \mathrm{H})$, $7.17(\mathrm{dd}, J=16.8,8.2 \mathrm{~Hz}, 2 \mathrm{H}), 5.43(\mathrm{~s}, 1 \mathrm{H}), 4.97(\mathrm{~d}, J=11.6 \mathrm{~Hz}, 1 \mathrm{H})$, $4.85(\mathrm{~d}, J=9.6 \mathrm{~Hz}, 1 \mathrm{H}), 4.44(\mathrm{~d}, J=11.4 \mathrm{~Hz}, 1 \mathrm{H}), 2.77(\mathrm{bs}, 2 \mathrm{H}), 2.11-$ $2.01(\mathrm{~m}, 2 \mathrm{H}), 1.95(\mathrm{t}, J=13.1 \mathrm{~Hz}, 2 \mathrm{H}), 1.87-1.63(\mathrm{~m}, 4 \mathrm{H}), 1.55-1.48$ $(\mathrm{m}, 2 \mathrm{H}), 1.46-1.38(\mathrm{~m}, 2 \mathrm{H}) .{ }^{13} \mathrm{C}$ NMR $\left(151 \mathrm{MHz}, \mathrm{CDCl}_{3}\right) \delta 143.4,142.3$, 132.4, 131.3, 131.1, 130.3, 128.1, 128.0, 125.4, 125.2, 96.9, 92.4, 69.9, 33.7, 32.7, 32.3, 29.4, 22.3, 17.7. Elemental analysis calcd. for $\mathrm{C}_{11} \mathrm{H}_{12} \mathrm{Cl}_{2} \mathrm{O}_{2}: \mathrm{C}, 53.47 ; \mathrm{H}, 4.89 ; \mathrm{Cl}, 28.69 ; \mathrm{O}, 12.95$. Found: $\mathrm{C}, 53.40 ; \mathrm{H}$, 4.85 .

\section{Acknowledgements}

This work was supported in part by the Italian Ministero dell'Istruzione, dell'Università e della Ricerca (MIUR) in the context of the projects PRIN2015LZE994 and "Development and application of $Q M / M M$ technologies for the design of light responsive proteins or protein-mimics based on rhodopsin architecture" within the program "Dipartimenti di Eccellenza - 2018-2022". A special thanks to Prof. Maurizio Taddei for discussions and suggestions. Thanks to Elisabetta Monciatti and Dr. Andrea Bernini for helping with NMR studies.

\section{Conflict of Interest}

The authors declare no conflict of interest.

Keywords: Hydroformylation - micellar catalysis - microwave cyclic acetals

[1] a) O. Roelen, Angew. Chem. 1948, 60, 62, 213; b) B. Corlins, W. A Herrmann, M. Rasch Angew. Chem. Int. Ed. 1994, 33, 2144; c) R. L. Pruett Adv. Organomet. Chem. 1979, 17, 1-60.

[2] a) M. Taddei, A. Mann, Hydroformylation for Organic Synthesis In Topics in Current Chemistry, Vol. 342 Eds. Springer-Verlag, Berlin, 2013; b) G. D. Cuny, S. L. Buchwald, J. Am. Chem. Soc. 1993, 115, 2066-2068.

[3] R. Franke, D. Selent, A. Börner Chem. Rev. 2012, 112, 5675-5732.

[4] L. Summerton, H. F. Sneddon, L. C. Jones, J. H. Clark, RSC Green Chemistry Book Series, 2016.

[5] a) P. J. Dunn, Chem. Soc. Rev, 2012, 41, 1452; b) P. J. Dunn, A. S. Wells, M. T. Williams Green Chemistry in the Pharmaceutical Industry Eds. Wiley, Weinheim, 2010.

[6] C. J. Cobley, C. H. Hanson, M. C. Loyd, S. Simmonds Org. Process Res. Dev. 2011, 15, 284-290.

[7] Z. A. Kasun, X. Gao, R. M. Lipinski, M. J. Krische, J. Am. Chem. Soc. 2015 137, 8900-89003.

[8] K. B. Rajurkar, S. S. Tonde, M. R. Didgikar, S. S. Joshi, R. V. Chaudhari Ind. Eng. Chem. Res. 2007, 46, 8480-8489.

[9] C. G. Vieira, E. N. Dos Santos, E. V. Gusevskaya Appl. Catal. A 2013, 446, 208-215.

[10] P. Sun, C. Sun, S. M. Weinreb J. Org. Chem. 2002, 67, 4337-4345.

[11] E. Airiau, N. Girard, M. Pizetti, J. Salvadori, M. Taddei, A. Mann J. Org. Chem. 2010, 75, 8670-8673.

[12] a) U. Ritte, N. Winkhofer, H. G. Schmidt, H. W. Roesky Angew. Chem. Int Ed. 1996, 35, 524-526; Angew. Chem. 1996, 108, 591-593; b) D. M. Hood, R. A. Johnson, A. E. Carpenter, J. M. Younker, D. J. Vinyard, G. G. Stanley, Science 2020, 367, 542-548.

[13] R. A. Sanchez-Delgado, J. S. Bradley, G. Wilkinson, J. Chem. Soc. Dalton Trans. 1976, 399-404

[14] I. Schwager, J. F. Knifton J. Catal. 1976, 45, 256-267. 
[15] S. Pandey, K. V. Raj, D. R. Shinde, K. Vanka, V. Kashyap, S. Kurungot, C. P. Vinod, S. H. Chikkali J. Am. Chem. Soc. 2018, 140, 4430-4439.

[16] a) J. A. Osborn, G. Wilkinson, J. F. Young, Chem. Commun. 1965, 2, 17; b) P. W. N. M. Van Leeuwen, C. Claver, Rhodium catalyzed hydroformylation Eds. Springer, Berlin, 2002.

[17] a) I. Ojima, C. Y. Tsai, M. Tzamarioudaki, D. Bonafoux Org. React. 2000 56, 1-354; b) M. Beller, B. Cornils, C. D. Frohning, C. W. Kohlpaintner, J. Mol. Catal. A. 1995, 104, 17-85.

[18] B. Breit, W. Seiche Synthesis 2001, 1-36

[19] a) D. Evans, J. A. Osborn, G. Wilkinson J. Chem. Soc. A 1968, 3134-3146; b) Y. Wu, Y. Shi, J. You Angew. Chem. Int. Ed. 2019, 58, 1-6.

[20] G. Wilkinson, US3501531, 1970.

[21] E. Petricci, A. Mann, A. Schoenfelder, A. Rota, M. Taddei, Org. Lett. 2006, 8, 3725-3727.

[22] E. Petricci, E. Cini, M. Taddei, Eur. J. Org. Chem. 2020, 4435-4446.

[23] T. Verheyen, N. Santillo, D. Marinelli, E. Petricci, W. De Borggraeve, L. Vaccaro, M. Smet, ACS Appl. Polym. Mater. 2019, 1, 1496-1504.

[24] a) E. Petricci, E. Cini, Top. Curr. Chem. 2013, 342, 117-149; b) E. Airiau, C. Chemin, N. Girard, G. Lonzi, A. Mann, E. Petricci, J. Salvadori, M. Taddei, Synthesis 2010, 2901-2914; c) F. Cardullo, D. Donati, G. Merlo, A. Paio, E. Petricci, M. Taddei, Synlett 2009, 47-50; d) E. Petricci, A. Mann, J. Salvadori, M. Taddei, Tetrahedron Lett. 2007, 48, 8501-8504.

[25] a) G. Oehme, Applied Homogeneous Catalysis with Organometallic Compounds: A Comprehensive Handbook (Vol. 2, $2^{\text {nd }}$ ed.) Eds.: B. Cornils, W. A. Herrmann, Wiley-VCH, Weinheim, Germany 2002, pp. 835-841; b) B. Cornils, W. A. Herrmann, Aqueous-Phase Organometallic Catalysis: Concepts and Applications (2 ${ }^{\text {nd }}$ Ed.), Eds.: Wiley-VCH, Weinheim, Germany, 2004, pp. 256-271; c) P. P. Bora, M. B. Bihani, S. Plummer, F. Gallou, S. Handa, ChemSusChem 2019, 12, 3037-3042; d) S. Sharma, J. Das, W. M. Braje, A. K. Dash, S. Handa, ChemSusChem 2020, 13, 2859-2875; e) U. Duong, T. Ansari, S. Parmar, S. Sharma, P. Kozlowski, J. Jasinski, S. Plummer, F. Gallou, S. Handa, ACS Sustainable Chem. Eng. 2021, 9 , 2854-2860; f) T. N. Ansari, J. B. Jasinski, D. K. Leahy, S. Handa, J. Am. Chem. Soc. Au 2021, 1, 308-315.

[26] a) B. H. Lipshut, Curr. Opin. Green Susten. Chem. 2018, 11, 1-8; b) B. H. Lipshutz, Johnson Matthey, Technol. Rev. 2017, 61, 196-202; c) F. Gallou R. Ostaszewski, P. Walde, S. Serrano-Luginbühl, K. Ruiz-Mirazo, Nat Chem. Rev. 2018, 2, 306-327; d) M. P. Andersson, F. Gallou, P. Klumphu, B. S. Takale, B. H. Lipshutz, Chem. Eur. J. 2018, 24, 6778-6786; e) B. H. Lipshutz, S. Ghorai, Green Chem. 2014, 16, 3660-3679; f) B. H. Lipshutz, S. Ghorai, Aldrichimica Acta 2012, 45, 3-16; g) M. Cortes-Clerget, N. Akporji, J. Zhou, F. Gao, P. Guo, M. Parmentier, F. Gallou, J.-Y. Berthon, B. H. Lipshutz, Nat. Commun. 2019, 10, 2169; h) D. J. Lippincott, E. Landstrom, M. Cortes-Clerget, B. H. Lipshutz, K. Buescher, R. Schreiber, C. Durano, M. Parmentier, Ning Ye, B. Wu, M. Shi, H. Yang, M. Andersson, F. Gallou, Org. Process Res. Dev. 2020, 24, 841-849.

[27] a) K. W. Anderson, S. L. Buchwald Angew. Chem. Int. Ed. Engl. 2005, 44, 6173-6177; b) M. Mondal, U. Bora Green Chem. 2012, 14, 1873-1876.

[28] G. La Sorella, G. Strukul, A. Scarso Green Chem. 2015, 17, 644-683.

[29] a) C. Risi, E. Cini, E. Petricci, S. Saponaro, M. Taddei Eur. J. Inorg. Chem. 2020, 1000-1003; b) C. Risi, M. Calamante, E. Cini, V. Faltoni, E. Petricci, F. Rosati, M. Taddei Green Chem. 2020, 22, 327-331.

[30] a) F. Schmidt, B. Zehner, W. Korth, A. Jess, M. Cokoja Catal. Sci. Technol. 2020, 10, 4448; b) F. Gallou, N. A. Isley, A. Ganic, U. Onken, M. Parmentier, Green Chem. 2016, 18, 14-19; c) J. D. Smith, T. N. Ansari, M. P. Andersson, D. Yadagiri, F. Ibrahim, S. Liang, G. B. Hammond, F. Gallou, S. Handa Green Chem. 2018, 20, 1784; d) M. Bihani, Tharique N. Ansari, L. Finck, P. P. Bora, J. B. Jasinski, B. Pavuluri, D. K. Leahy, S. Handa, ACS Catal. 2020, 10, 6816-6821.

[31] a) Kuntz, E. G. FR Pat. 2.349.562.1976, 1976; b) B. Cornils, J. Hibbel, W. Konkol, B. Lieder, J. Much, V. Schmidt, E. Wiebus (Ruhrchemie AG, Oberhausen), DE3234701, 1982.

[32] M. J. Hayling, B. A. Murrer, GB2085874A, Johnson Matthey, 1982

[33] a) A. Riisager, B. E. Hanson, J. Mol. Catal. A 2002, 189, 195-202; b) C. C. Miyagawa, J. Kupka, A. Schumpe, J. Mol. Catal. A 2005, 234, 9-17; c) S. L. Desset, D. J. Cole-Hamilton, D. F. Fosterb, Chem. Commun. 2007, 19331935; d) S. L. Desset, S. W. Readera, D. J. Cole-Hamilton, Green Chem 2009, 11, 630-637; e) X. Zhang, A. F. Cardozo, S. Chen, W. Zhang, C. Julcour, M. Lansalot, J.-F. Blanco, F. Gayet, H. Delmas, B. Charleux, E. Manoury, F. D'Agosto, R. Poli, Chem. Eur. J. 2014, 20, 15505-1551; f) A. F. Cardozo, C. Julcour, L. Barthe, J.-F. Blanco, S. Chen, F. Gayet, E. Manoury, X. Zhan, M. Lansalot, B. Charleux, F. D'Agosto, R. Poli, H. Delmas, J. Catal. 2015, 324, 1-8; g) E. Lobry, A. F. Cardozo, L. Barthe, J.-F. Blanco, H. Delmas, S. Chen, F. Gayet, X. Zhang, M. Lansalot, F. D'Agosto, R. Poli, E. Manoury, C. Julcour, J. Catal. 2016, 342, 164-172; h) D. Stehl, N.
Milojević, S. Stock, R. Schomäcker, R. von Klitzing, Ind. Eng. Chem. Res. 2019, 7, 2524-2536; i) D. Peral, D. Stehl, B. Bibouche, H. Yu, J. Mardoukh, R. Schomäcker, R. von Klitzing, D. Vogt, J. Colloid Interface Sci. 2018, 513, 638-646.

[34] a) A. F. Borowski, D. J. Cole-Hamilton, G. Wilkinson Nouv. J. Chim. 1978, 2, 137; b) K. Kurtev, D. Ribola, R. A. Jones, D. J. Cole-Hamilton, G Wilkinson, J. Chem. Soc. Dalton Trans. 1980, 55-58; c) R. T. Smith, R. K. Ungar, L. J. Sanderson, M. C. Baird, Organometallics 1983, 2, 1138-1139; d) M. K. Markiewicz, M. C. Baird, Inorg. Chim. Acta 1986, 113, 95-99; e) T. Bartik, B. B. Bunn, B. Bartik, B. E. Hanson, Inorg. Chem. 1994, 33, 164-169; f) S. Lelièvre, F. Mercier, F. Mathey, J. Org. Chem. 1996, 61, 3531-3533 g) F. P. Pruchnik, P. K. Wajda-Hermanowicz, J. Organomet. Chem. 1998, 570, 63-69; h) M. Beller, J. G. E. Krauter, A. Zapf, S. Bogdanovic, Catal. Today 1999, 48, 279-290; i) J.-X. Gao, P.-P. Xu, X.-D. Yi, H.-L. Wan, K.-R. Tsai, J. Mol. Catal. A 1999, 147, 99; j) S. Bischoff, M. Kant, Ind. Eng. Chem Res. 2000, 39, 4908-4913.

[35] L. Obrecht, P. C. J. Kamer, W. Laan, Catal. Sci. Technol. 2013, 3, 541-551.

[36] M. Schwarze, T. Pogrzeba, K. Seifert, T. Hamerla, R. Schomäcker, Catal. Today 2015, 247, 55-63.

[37] M. Illner, D. Müller, E. Esche, T. Pogrzeba, M. Schmidt, R. Schomac"ker, G. Wozny, J.-U. Repke, Ind. Eng. Chem. Res. 2016, 55, 8616-8626.

[38] T. Pogrzeba, M. Schmidt, L. Hohl, A. Weber, G. Buchner, J. Schulz, M. Schwarze, M. Kraume, R. Schomac"ker, Ind. Eng. Chem. Res. 2016, 55, $12765-12775$.

[39] a) T. Pogrzeba, D. Müller, T. Hamerla, E. Esche, N. Paul, G. Wozny, R. Schomäcker, Ind. Eng. Chem. Res. 2015, 54, 11953-11960; b) T. Pogrzeba, M. Schmidt, N. Milojevic, C. Urban, M. Illner, J.-U. Repke, R. Schomäcker, Ind. Eng. Chem. Res. 2017, 56, 9934-9941.

[40] B. Bibouche, D. Peral, D. Stehl, V. Söderholm, R. Schomäcker, R. von Klitzing, D. Vogt, RSC Adv. 2018, 8, 23332-23338.

[41] A. T. Straub, M. Otto, I. Usui, B. Breit, Adv. Synth. Catal. 2013, 355, 20712075.

[42] S. Siangwataa, N. J. Goosenb, G. S. Smitha, Appl. Catal. A 2020, 603, 117736.

[43] a) K. U. Kuennemann, L. Schurm, D. Lange, T. Seidensticker, S. Tilloy, E. Monflier, D. Vogt, J. M. Dreimann, Green Chem. 2020, 22, 3809-3819; b) A. Cocq, H. Bricout, F. Djedaini-Pilard, S. Tilloy, E. Monflier Catalysts 2020, 10, 56.

[44] C. Plass, A. Hinzmann, M. Terhorst, W. Brauer, K. Oike, H. Yavuzer, Y. Asano, A. J. Vorholt, T. Betke, H. Gröger ACS Catal. 2019, 9, 5198-5203.

[45] K. Dong, Q. Sun, Y. Tang, C. Shan, B. Aguila, S. Wang, X. Meng, S. Ma, F.S. Xiao Nat. Commun. 2019, 10, 1-8.

[46] T. Hamerla, A. Rost, Y. Kasaka, R. Schomäcker, ChemCatChem 2013, 5, 1854-1862.

[47] M. Zubair, R. Ferrari, O. Alagha, N. D. Mu'azu, N. I. Blaisi, I. S. Ateeq, M. S. Manzar Polymer 2020, 12, 2477.

[48] L. S. Gangurde, G. D. S. J. Sturm, T. J. Devadiga, A. I. Stankiewicz, G. D. Stefanidis, Ind. Eng. Chem. Res. 2017, 56, 13379-13391.

[49] C. C. Lau, M. K. Bayazit, P. J. T. Reardon, J. Tang, Chem. Rec. 2019, 19, 172-187.

[50] P. Priecel, J. A. Lopez-Sanchez, ACS Sustainable Chem. Eng. 2019, 7, 321.

[51] SAIREM. Industrial microwave assisted processing in chemistry: https:// www.sairem.com.

[52] A. Aguilar-Reynosa, A. Romaní, R. Rodríguez-Jasso, C. N. Aguilar, G. Garrote, H. A. Ruiz, Energy Convers. Manage. 2017, 136, 50-65.

[53] Y. Zhang, C. G. Fry, J. A. Pedersen, R. J. Hamers, Anal. Chem. 2017, 89, 12399-12407.

[54] S. Pomplun, C. Sippel, A. Hähle, D. Tay, K. Shima, A. Klages, C. Murat Ünal, B. Rieß, H. Ting Toh, G. Hansen, H. S. Yoon, A. Bracher, P. Preiser, J. Rupp, M. Steinert, F. Hausch, J. Med. Chem. 2018, 61, 36603673

[55] M. Rahman, G. Li, M. Szostak J. Org. Chem. 2019, 84, 12091-12100.

[56] B. Nammalwar, N. Prasad, M. Field, M. W. Richard, A. Bunce Tetrahedron 2015, 71, 9101-9111.

[57] A. P. Häring, P. Biallas, S. F. Kirsch, Eur. J. Org. Chem. 2017, 1526-1539.

[58] M. Szigeti, Z. Dobi, T. Soós, J. Org. Chem. 2018, 83, 2869-2874.

[59] A. K. Chakraborti, S. V. Chankeshwara, J. Org. Chem. 2009, 74, 13671370.

[60] J. N. Moorthy, K. N. Parida, J. Org. Chem. 2014, 79, 11431-11439.

[61] Y. Ogiwara, Y. Sakurai, H. Hattori, N. Sakai, Org. Lett. 2018, 20, 42044208.

[62] J.-A. Jiang, J.-L. Du, Z.-G. Wang, Z.-N. Zhang, X. Xu, G.-L. Zheng, Y.-F. Ji, Tetrahedron Lett. 2014, 55, 1677-1681. 
[63] X. Zhang, B. Cao, S. Yu, X. Zhang, Angew. Chem. Int. Ed. 2010, 49, 4047

[69] Y. Matsumoto, M. Yonaga, Synlett 2014, 1764-1768. 4050; Angew. Chem. 2010, 122, 4141-4144.

[64] A. V. losub, S. Moravčík, C.-J. Wallentin, J. Bergman, Org. Lett. 2019, 21, 7804-7808.

[65] K.-F. Hu, X.-S. Ning, J.-P. Qu, Y.-B. Kang, J. Org. Chem. 2018, 83, 1132711332.

[66] A. Boto, R. Hernández, E. Suárez, J. Org. Chem. 2000, 65, 4930-4937.

[67] B. S. L. Collins, M. G. Suero, M. J. Gaunt, Angew. Chem. Int. Ed. 2013, 52, 5799-5802; Angew. Chem. 2013, 125, 5911-5914.

[68] A. Nagaki, H. Yamashita, Y. Takahashi, S. Ishiuchi, K. Imai, J.-I. Yoshida, Chem. Lett. 2018, 47, 71-73.

Manuscript received: February 3, 2021

Revised manuscript received: March 16, 2021

Accepted manuscript online: March 24, 2021

Version of record online: May 5, 2021 